\title{
A review: Antimicrobial activity of the medicinal spice plants to cure human disease
}

\author{
Varsha Mahesh Mayekar, Ahmad Ali, Hina Alim \& Nimisha Patel ${ }^{*}$ \\ Department of Life Sciences, University of Mumbai, Vidyanagari, Santacruz (East), Mumbai 400 098, India \\ *Email: patelnimisha916@gmail.com
}

\section{ARTICLE HISTORY}

Received: 03 March 2021

Accepted: 29 April 2021

Available online: 01 July 2021

\section{KEYWORDS}

Antimicrobial activity

Human pathogens

Medicinal plants

Microorganisms

Spices

\begin{abstract}
Since the ancient time medicinal plants and spices are used as herbal medicine because of their medicinal values. They are the valuable resources of the natural antimicrobial compounds used to treat the infectious disease caused by bacteria and other pathogens. Plant's extract, essential oil and numerous kinds of secondary compounds had antibacterial, antiviral, antifungal and antioxidants activities with less or no toxic effects; that are essential to cure many diseases. The compounds isolated from the medicinal spice plants show antimicrobial activity against some bacterial strains that has the ability to affect the food quality and shelf life of the food. These plants have various medicinal properties like anti-inflammatory action, tonic, expectorants, diuretics, astringents, digestives, carminative, antibiotics and stimulants etc. The spectrum of compounds present in medicinal spice plants, and the structure of major compounds discussed in this review, are responsible for all of their medicinal properties. Therefore, plants are used in the form of maceration, fluid extracts, oil, syrup, juice, decoction, powder, tea and ointments. In the terms of the frequencies and configuration of various radicals both medicinal plants and antibiotics are different. Since plant-based products have no toxicity, also less costly than conventional drugs, research on the compounds found in medicinal plants and their action against harmful microbial species should be conducted in order to improve human health and expand the use of medicinal plants. Plants also have the ability to inhibit or alter proteinprotein interactions, making them a powerful modulator of signal transduction, apoptosis, mitosis and immune response.
\end{abstract}

\section{Introduction}

For the specific antimicrobial property, the growth of bacterial resistance to available medicinal products was appropriate. Gram positive microorganisms like Staphylococcus species are responsible for diseases such as osteomyelitis, food poisoning, toxic shock syndrome and several infections. Gram negative microorganisms like Escherichia sp. causes Pneumonia, lower urinary tract infection, bacterial infection and septicemia etc. (1). Plants are naturally God gifted for the synthesis of medicinal compounds. Since the ancient time some plants are used as herbal medicine because of their medicinal values (3). Therefore, these medicinal plants are the valuable resources of the natural antimicrobial compounds used to treat the infections caused by bacteria and other pathogens. World Health Organization (WHO) stated that the medicinal plants are the best source to obtain the variety of drugs (2).
On the basis of traditional and modern medicines plants; their natural products were used to manufacture the commercially valuable medicines. (6). Plant's extract, essential oil and numerous kinds of secondary compounds had antibacterial, antiviral, antifungal and antioxidants activities with the less or no toxic effects that are essential in the management of many diseases (7). Actually, secondary compounds such as alkaloids, flavonoids, terpenoids, steroids, carotenoids and other phenolic compounds are known as phytochemicals. They are present in different parts of the plants. These phytochemicals are used for drug developments to treat many serious diseases such as respiratory disease, urinary tract infections, cutaneous infections and gastrointestinal disorder. They have a high therapeutic value (8). Artemisia vulgaris, Boerhavia procumbens, Carum copticum, Euphorbia hirta, Hyoscyamus niger and Zingiber officinale are the group of plants used against the respiratory problems (9). 
From the past few years, various attempts have been put forward to discover the advanced antimicrobial compounds from the different kind of natural resources (10). These days, the determination of the antimicrobial activities of the various medicinal plants is of particular importance because of the ongoing conditions in which the pathogens develop medicinal resistance. There is a need to keep low approach to prevent and treat different infections caused by bacterial, viral, fungal pathogens by antibiotics to narrow down antimicrobial resistance. Therefore, the most essential step is to evaluate the components that helped to create medicines with higher antimicrobial properties (3). For food preservation antimicrobial compounds are isolated from the plants and used. Chinese, Indians and Egyptians used spices and essential oil since the ancient times to preserve the food. Some spices such as ginger, garlic, mint, turmeric, pepper, nutmeg, cloves, cinnamon etc. are produced in Asia $(14,15)$. In America ginger, pepper, sesame seeds and nutmeg plants are cultivated. In Europe celery leaves, watercress, bay leaves, dill tips, basil, coriander and thymus are grown on huge scale (15).

Because of their preservative properties spices have been used in cosmetics, perfumes, in ritual, flavoring, coloring and have also been used in traditional food preparation methods of food industries (13). Even many compounds could be isolated from the spices and shows the antimicrobial activity against some bacterial strains that has the ability to affects the food quality and shelf life of the food. They have various kinds of beneficial effects such as promotes the secretion of saliva, aids digestion, also helpful in the treatment of cold to reduce nausea and vomiting (15).

Plant derived components and their phytochemicals has been used in the treatment of various infectious diseases. Uses of plants shows low or zero toxicity. They are sometimes sufficient as antibiotics, so we combined them with antibiotics to reduce bacterial antibiotic resistance (92). In this review article, the brief overview of the antimicrobial activities of the spices and medicinal plants is discussed that are used to treat the human disease globally. To assess the antimicrobial and synergistic effects of the medicinal plants, the extracts with the antibiotic and non-antibiotic drugs against the microorganisms are used.

\section{Methodology}

In this review data is collected on the antimicrobial properties of various medicinal plants and spices. The data is collected on the plants that have higher antimicrobial activity against specific pathogens. Also, some of them are easily available and cultivable. For this we referred more than 100 articles both review as well as research articles that were published between 2015 and 2021. Hence, the information in this review article is current and up to date.

\section{History of use of medicinal plants and spices}

World Health Organization (WHO) stated that the medical plants are the best source to obtain the drugs and the $80 \%$ of world population are dependent on the traditional medicines (8). From ages, In Asia plants were used as medicine with the human involvement. The herbal medicine contains the different types of unique substance to treat infectious and chronic disease (7). According to the ancient recorded data around 5000-year-old records were founded that describes the usage of medicinal plants to prepare the medicines. It comprised 12 recipes for drug preparation referring to 250 different plants; some of them use alkaloid such as poppy, henbane and mandrake. Back then as the exact causes of the disease were not known and so the plants were used to treat the disease; but everything was experimented about the use of plants to cure the diseases (16).

- Chinese books based on roots and grasses 'Pen T. Sao' written by emperor Shen Nung Circa in $2500 \mathrm{BC}$, by using the dry parts of plants, the 365 drugs were reported and prepared. Many of these plants are used till now for e.g., cinnamon bark, Theae folium, Jimson weed, camphor, great yellow gentian, Ephedra, Rhei rhizoma, Podophyllum and ginseng (17).

- In Egypt Papyrus Ebers is book written around $1550 \mathrm{BC}$, it has the combination of 700 plants species for e.g., coriander, onion, garlic, aloe, castor oil, pomegranate etc. these plants are used in therapy (18).

- Roman and Greek added extensively to the coherent development of the use of traditional medicine in the ancient time and written the use of medicine, collection of them in "known world." Natural products that are sold as herbal and/or food supplements for medications covers half of the main 50 drugs sold in European pharmacies (19).

In India, history of traditional medicines and its health-care record goes back to 5000 years BCE, when health-care needs and diseases were noted in ancient literature such as "Rig-Veda" (1700-1100 BCE), "YajurVeda" (1400-1000 BCE) and "Atharva Veda" (1200 $\mathrm{BCE})$. Later, the manuscripts such as "Dhanwantari Nighantu” (1800 CE), "Charaka Samhita” (990 BCE) and "Sushruta Samhita" (660 BCE), where the use of plants and poly herbal formulations was emphasized and widely practised as shown in the Fig. 1 (20).

Traditional medicine means the practice of medicines originated in India or else came into India from the outside country and eventually absorbed into the Indian culture. This medicinal system includes Ayurveda, Siddha and Unani (6). Ayurveda means 'science of life'. The central objective of the Ayurveda treatment is that "its deal with the life and gives the knowledge of life, also it measures the quality and expectancy of life (19).

Recently COVID-19 infection is declared by the WHO as a global pandemic. It was a tremendously infectious disease. It was caused by SARS-CoV-2 virus (21). The plants can produce many important chemical components through their secondary 


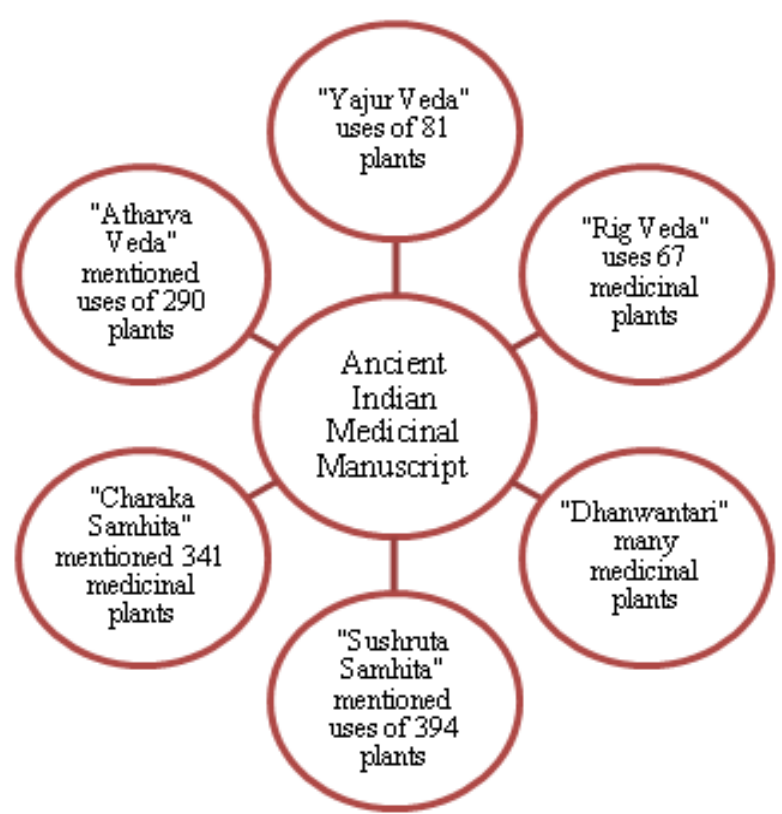

Fig. 1. Enlisted ancient Indian medicinal manuscripts (Source: 20).

metabolism, that operates as a self-defense against the stress induced by the environmental triggers and pathogens (9). In this situation, preventive and therapeutic agents have not been established and recommended, globally the use of medicinal plants is advised to prevent the COVID -19 (79). The medicinal spice plants serve as the effective medicine to treat the infection due to their antipyretic, antioxidant, anti-inflammatory, antiviral, cyto-protective and immunomodulatory properties (5).

\section{Antimicrobial activity of the spices}

For human beings, spices have been important since the beginning. Several mythological evidences from the sacred books such "Bhagavad Gita" suggest the use of the spices for several purposes. The spices are commonly used for the preservation purpose due to their strong preservative quality and according to the Ayurveda, the plants with medicinal properties helps to maintain the balance of the body moisture (6). Also, they change the appearances of the food and spices such as, chilli powder, turmeric, coriander powder etc. used to change the color, appearance and taste of the food. Some spices like ginger, nutmeg and cinnamon improve the digestion, also good for sore throats (18). In the last few years numerous articles describe the antimicrobial properties of spices. Plant parts and its extract dissolved with solvents like water, ethyl acetate, methanol, ethanol etc. to test their antimicrobial activity against the microorganisms (15). Therefore, these plants are used in the form of maceration, fluid extracts, oil, syrup, juice, decoction, powder, tea and ointments etc. Essential oil derived from these spices has been used in the treatment of anxiety and stress, depression and aromatherapy since they have been used for various purposes since ancient times (22). The major chemical components of coriander and mint have analgesic effects. Also, celery, coriander and cumin have anti-inflammatory effect (23). These plants are rich in natural important antioxidants. The Table 1 represents the various medicinal spices plants and the major compounds present in them which has antimicrobial activities against the various pathogens.

Table 1. The antimicrobial properties of the medicinal spices against pathogenic microbes

\begin{tabular}{|c|c|c|c|c|}
\hline Common name & Scientific name & Major components & Micro-organisms & References \\
\hline Ajwain, carom seed & Trachyspermum ammi & $\begin{array}{l}\text { B-Phellandrene, } \\
\text { a-Terpinene }\end{array}$ & $\begin{array}{l}\text { Candida albicans, } \\
\text { Salmonella species, } \\
\text { Escherichia coli }\end{array}$ & 38 \\
\hline Asafoetida & Ferula asafoetida & $\begin{array}{l}\text { Azulene, a-Pinene, } \\
\text { Ferulic acid, } \\
\text { Umbelliferone }\end{array}$ & $\begin{array}{l}\text { Bacillus subtilis, } \\
\text { Escherichia coli, } \\
\text { Staphylococcus aureus }\end{array}$ & 31 \\
\hline Black mustard & Brassica nigra & $\begin{array}{l}\text { Catechin, } \\
\text { Epicatechin, } \\
\text { Gallic acid, } \\
\text { Myricetin, } \\
\text { Quercetin, } \\
\text { Rutin } \\
\end{array}$ & $\begin{array}{l}\text { Staphylococcus aureus, } \\
\text { Pseudomonas aeruginosa, } \\
\text { Candida albicans, } \\
\text { Escherichia coli }\end{array}$ & 25 \\
\hline Black pepper & Piper nigrum & $\begin{array}{l}\text { Piperine, } \\
\text { Limonene, } \\
\text { Caryophyllene }\end{array}$ & $\begin{array}{l}\text { Pseudomonas aeruginosa, } \\
\text { Bacillus cereus, Escherichia } \\
\text { coli, Staphylococcus aureus }\end{array}$ & 34 \\
\hline Cinnamon & Cinnamomum verum & $\begin{array}{l}\text { Cinnamaldehyde, } \\
\text { Cinnamic acid, } \\
\text { Cinnamyl acetate }\end{array}$ & $\begin{array}{l}\text { Salmonella typhi, } \\
\text { Staphylococcus aureus, } \\
\text { Pseudomonas fluorescens, } \\
\text { Bacillus licheniformis, } \\
\text { Escherichia coli }\end{array}$ & 28 \\
\hline Clove & Syzygium aromaticum & Eugenol & $\begin{array}{l}\text { Escherichia coli, } \\
\text { Staphylococcus aureus, } \\
\text { Salmonella anatum, } \\
\text { Bacillus cereus }\end{array}$ & 36 \\
\hline Coriander & Coriandrum sativum & $\begin{array}{l}\text { Linalool, } \\
\text { Camphor, } \\
\text { Geraniol, } \\
\text { Limonene }\end{array}$ & $\begin{array}{l}\text { Pseudomonas aeruginosa, } \\
\text { Escherichia coli, } \\
\text { Salmonella aureus, } \\
\text { Bacillus pumilus }\end{array}$ & 29 \\
\hline
\end{tabular}




\begin{tabular}{|c|c|c|c|c|}
\hline Cumin & Cuminum cyminum & Cuminal & $\begin{array}{l}\text { Candida albicans, } \\
\text { Aspergillus niger, } \\
\text { Bacillus cereus } \\
\end{array}$ & 27 \\
\hline Fennel & Foeniculum vulgare & $\begin{array}{l}\text { Fenchone, } \\
\text { Estragole, } \\
\text { Anethole, }\end{array}$ & $\begin{array}{l}\text { Chlorella vulgaris, } \\
\text { Pseudomonas aeruginosa, } \\
\text { Escherichia coli, } \\
\text { Bacillus subtilis, } \\
\text { Bacillus cereus }\end{array}$ & 32 \\
\hline Fenugreek & Trigonella foenum-graecum & $\begin{array}{l}\text { Sapogenin, } \\
\text { Diosgenin }\end{array}$ & $\begin{array}{l}\text { Bacillus cereus, } \\
\text { Pseudomonas aeruginosa }\end{array}$ & 37 \\
\hline Garlic & Allium sativum & $\begin{array}{l}\text { Allicin, } \\
\text { Alliin, } \\
\text { Ajoene, } \\
\text { Allyl-cysteine, } \\
\text { Diallyl-sulfide } \\
\end{array}$ & $\begin{array}{l}\text { Salmonella typhi, } \\
\text { Bacillus cereus, } \\
\text { Bacillus subtilis, } \\
\text { Escherichia coli }\end{array}$ & 24 \\
\hline Ginger & Zingiber officinale & $\begin{array}{l}\text { Shogoal, } \\
\text { gingerol }\end{array}$ & $\begin{array}{l}\text { Salmonella typhi, } \\
\text { Escherichia coli, } \\
\text { Staphylococcus species }\end{array}$ & 39 \\
\hline Nutmeg & Myristica fragrans & $\begin{array}{l}\text { Myristicin, } \\
\text { Sabinene }\end{array}$ & $\begin{array}{l}\text { Aspergillus niger, } \\
\text { Pseudomonas aeruginosa, } \\
\text { Bacillus subtilis, } \\
\text { Staphylococcus aureus }\end{array}$ & 11 \\
\hline Sesame & Sesamum indicum & $\begin{array}{l}\text { Lignans, } \\
\text { Soya-cerebroside }\end{array}$ & $\begin{array}{l}\text { Streptococcus sp., } \\
\text { Candida albicans, } \\
\text { Escherichia coli }\end{array}$ & 35 \\
\hline Star anise & Illicium verum & $\begin{array}{l}\text { Anethole, } \\
\text { Caryophyllene }\end{array}$ & $\begin{array}{l}\text { Aspergillus niger, } \\
\text { Salmonella arizonae, } \\
\text { Escherichia coli, } \\
\text { Bacillus cereus }\end{array}$ & 33 \\
\hline Turmeric & Curcuma longa & Curcumin & $\begin{array}{l}\text { Escherichia coli, } \\
\text { Salmonella typhi, } \\
\text { Klebsiella pneumoniae, } \\
\text { Staphylococcus epidermis, } \\
\text { Penicillium notatum }\end{array}$ & 30 \\
\hline White mustard & Sinapis alba & $\begin{array}{l}\text { Allyl isothiocyanate Benzyl } \\
\text { nitrile, } \\
\text { Thymol }\end{array}$ & $\begin{array}{l}\text { Pseudomonas aeruginosa, } \\
\text { Campylobacter jejuni }\end{array}$ & 25 \\
\hline
\end{tabular}

The anti-microbial activity of different medicinal spices

\section{Clove}

Clove belongs to the family of Myrtaceae. It has antibacterial, antioxidant, insecticidal and antifungal properties. Also, it is used in food, and as an antiseptic medicine during oral infection. It contains eugenol, eugenyl acetate, vanillin, and humulene as the major compound as shown in Fig. 2 (40). This compound inhibits the production of amylase and protease enzyme in Bacillus cereus strain (36). Since clove compounds have antimicrobial properties, they can be used in the food industry and extend the shelf life of food (41).

\section{Antimicrobial activity of Clove}

The antibacterial activity of clove against the microorganisms like Staphylococcus aureus, Pseudomonas aeruginosa and Escherichia coli was examined by using the agar well diffusion method and MIC (The minimum inhibitory concentration) value determined by the broth dilution method. The result indicated that the methanolic extract of clove has the highest antibacterial activity as compare to ethanolic extracts against the $S$. aureus strain. The result shows the MIC value observed in the range of $2.31 \mathrm{mg} / \mathrm{mL}$ for $S$. aureus microorganism (43). The antimicrobial activity of essential oil of the clove, cinnamon and cardamom was tested against various microorganism, yeast and molds with the help of disc diffusion assay. It was observed that essential oil of clove shown the maximum antimicrobial properties (44). Eugenol, is the major component of the clove. In
Europe, US, China and other countries it is used for food preservation. Also, it was been used in oral product and beneficial to reduce tooth ache, oral bacteria, dental plaque, halitosis etc. (45).

\section{Oregano}

Oregano belongs to the family of Lamiaceae. Oregano is a perennial shrub and cultivated to be used as herbs as it has therapeutic properties (48). It shows the strong antioxidant capacity in the both dry and fresh forms. It has been used to treat respiratory disorder, indigestion and rheumatoid arthritis. It is also used in food flavoring as well in the storage of food items. It contains carvacrol and Thymol as major components (46) and other components as shown in Fig. 3.

\section{Antimicrobial activity of oregano}

The four-gram positive strains of methicillin resistant $S$. aureus and seven-gram negative strains of Acinetobacter baumannii and $P$. aeruginosa were used to study the antibacterial activity of oregano oil. The broth micro dilution method was used for the purpose. The result shows that the oregano oil can overcome the obstacle of biofilm formation and kill sufficient planktonic bacteria (68). The antimicrobial properties of some spice's plants were tested by using the agar diffusion method. It was observed that the antimicrobial activity of essential oil incorporates in series of: anise $>$ Basil $>$ Coriander $>$ Oregano. The oregano had shown the highest antimicrobial activity against S. aureus and Staphylococcus spp. Therefore, latest research should focus on the potential usage of oregano in various industries (48). 


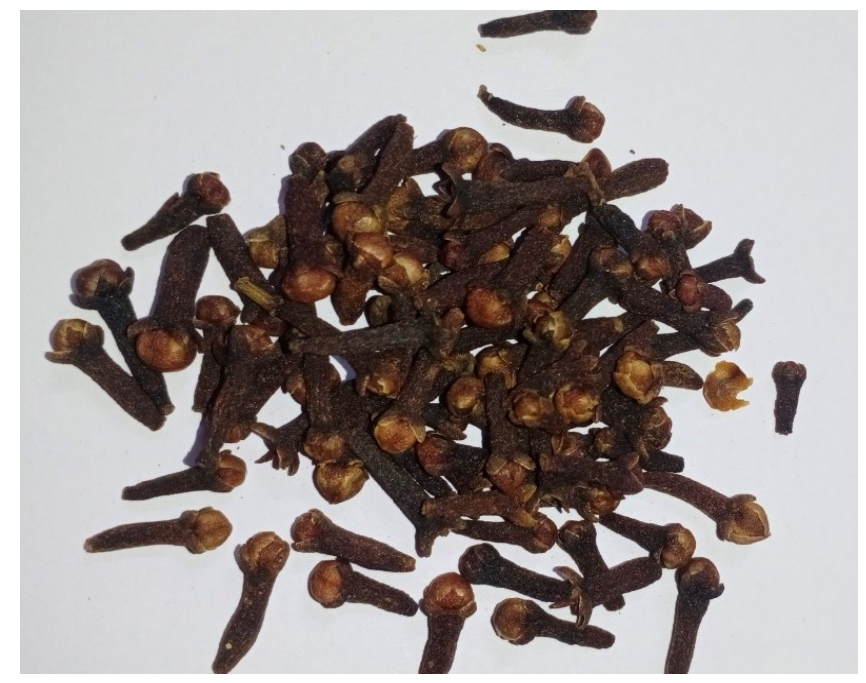

(a) Image of clove

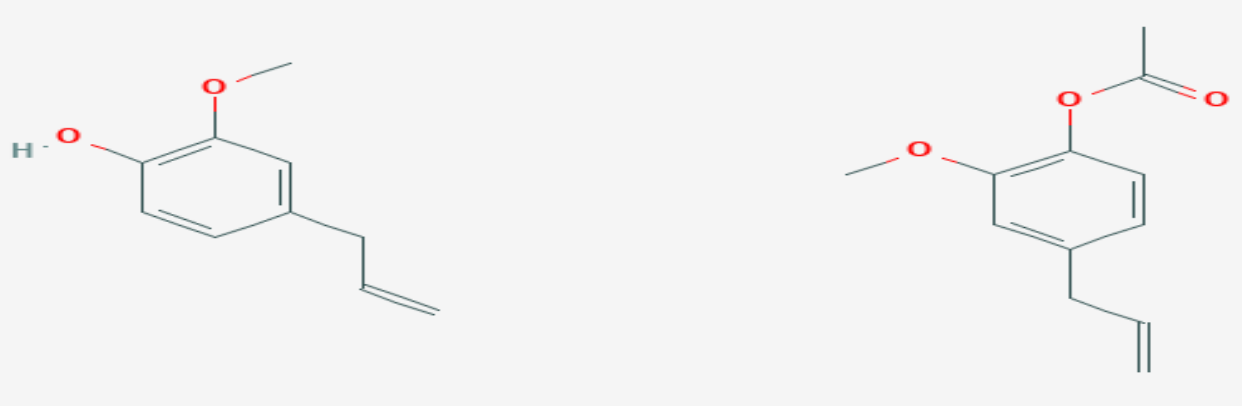

(b) 1. Eugenol

2. Eugenyl acetate

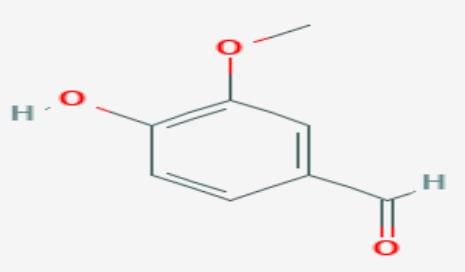

3. Vanillin

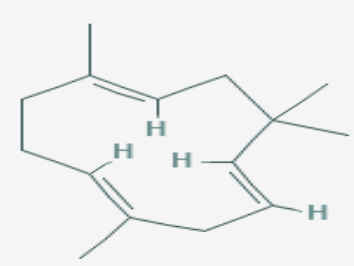

4. Humulene

Fig. 2. (a) Image of clove, (b) The chemical structure of compounds presents in the essential oil of the clove (source: 42 ).

\section{Cinnamon}

It belongs to the family of Lauraceae, it is widely used in the food preparations. It has 3 major components cinnamaldehyde, cinnamyl acetate and cinnamic acid as shown in Fig. 4. Mostly it was applied in food and cosmetics industries; but due to the presence of health promoting agents used in the treatment of some diseases like urinary infections, gastrointestinal disorders, inflammation etc. (28). It contains cinnamaldehyde as the main compound. This compound has antimicrobial effects against pathogenic bacterial strain, inhibits respective enzyme activity, membrane functioning and in the biosynthesis of cell wall. In traditional medicines, it used to relief high blood pressure, toothache, for wound healing, to improve the menstrual irregularity, arthritis and dermatitis (49).

\section{Antimicrobial activity of cinnamon}

The antimicrobial activity of some spices plants and aqueous extracts was studied against the bacterial strain via the aerobic plate count method and disc diffusion method. Cinnamon extract inhibits all the tested bacterial strains at different concentration ranging from 1 to $5 \% \mathrm{w} / \mathrm{v}$. The inhibitory effects on the bacterial growth increase with increasing concentrations of cinnamon extracts. The antimicrobial activity of the hydrolysate of different plants such as thyme, mustard, cinnamon, cardamom, clove and basil were evaluated on the bacterial strain. The $S$. aureus shows the highest sensitivity to cinnamon hydrosol, as compare to $P$. aeruginosa strain (51). The investigation on the antimicrobial property of some spice's ethanol extracts on the Enterococci strains was done with the help of well diffusion test. The result signified that 


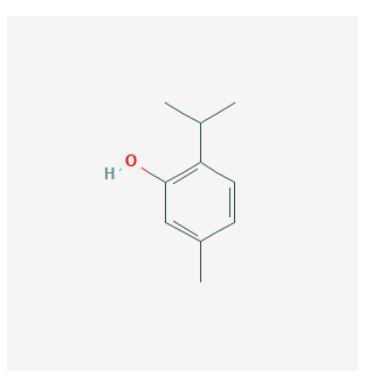

1. Thymol

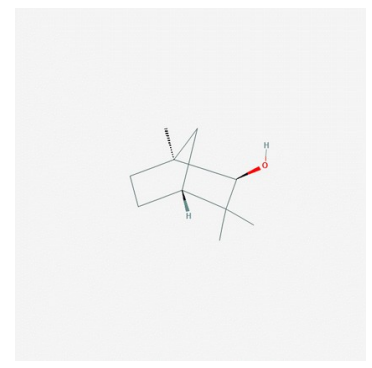

4. B- Fenchyl alcohol

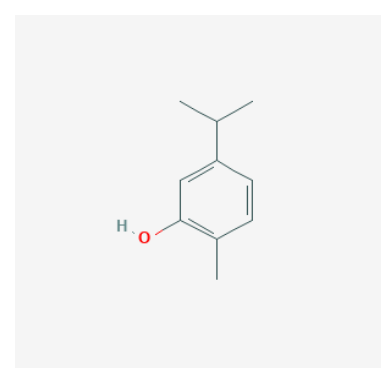

2. Carvacrol

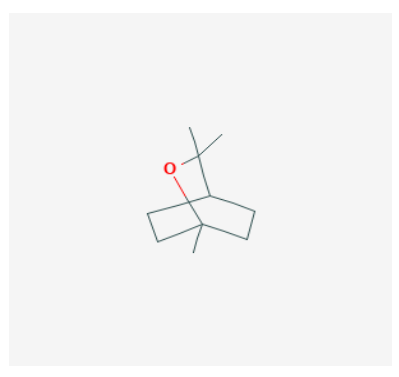

5. Eucalyptol

Fig. 3. The chemical structure of compounds presents in oregano extract (source: 47).

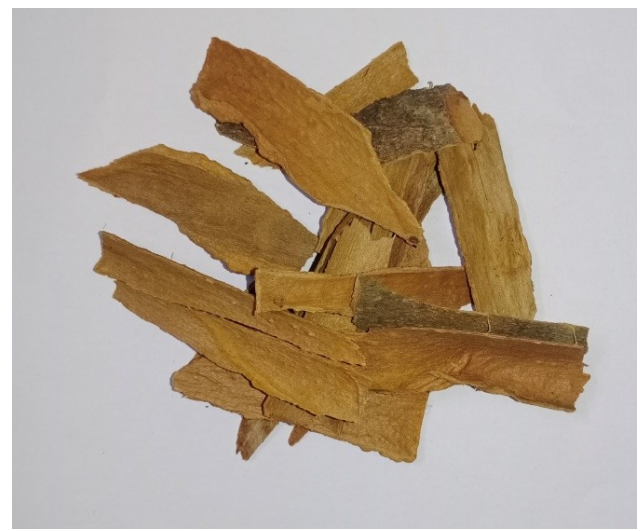

(a) Image of cinnamon

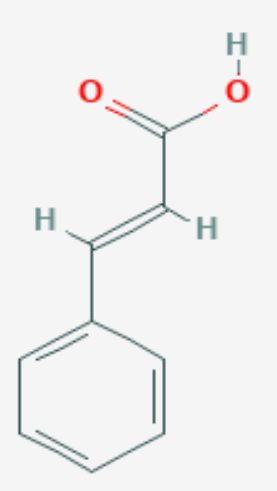

(b) 1. Cinnamic acid

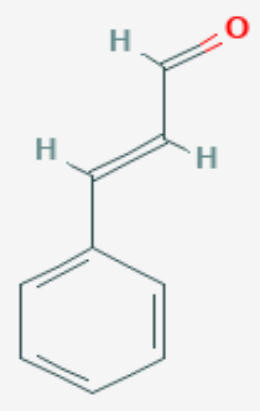

2. Cinnamaldehyde

\section{3. $\mathrm{\gamma}$ - Terpinene}

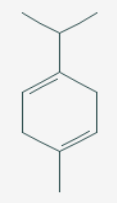

Fig. 4. (a) Image of cinnamon, (b) The chemical structure of the compounds of cinnamon (source: 50). 
ethanol extract of cinnamon shows the antimicrobial activity against all the strains of Enterococci. Furthermore, the antimicrobial activity of cinnamon essential oil tested on the various microorganisms and it was observed that as compare to fungi, bacteria showed less sensitivity to essential oil of cinnamon. The MIC value was observed in the range of $0.015-2.0 \mathrm{mg} / \mathrm{mL}$ against all the tested microorganisms (52).

\section{Ginger}

Ginger belongs to the family Zingiberaceae, it is a horizontally branched, fleshy and aromatic white to yellow colored herb. It was mainly applied in cosmetics, pharmaceutical products, and also used extensively in food production. It is known for its nutraceutical value. The Fig. 5 represents that it contains the gingerol and shogaol as major components (53). In traditional medicine it is used to treat cramps, rheumatism, fever, dementia, arthritis, muscular ache, sore throat, pain, vomiting, indigestion, hypertension, sprain and infectious disease. It has antimicrobial activity therefore it could be used in the treatment of bacterial infections (54).

\section{Antimicrobial activities of ginger}

The ginger leaves oil was extracted, analyzed with the help of the gas chromatography and mass spectroscopy. The results showed the presence of different compounds in the extracted oil. The antibacterial activity of the ginger was tested against the Streptococcus mutans ATCC 25175 by using the agar diffusion method. The result demonstrated that ginger leaves volatile oil was rich in valuable phyto constituents and was effective against $S$. mutans. The MIC value detected was $62.5 \mu \mathrm{g} / \mathrm{mL}$. It is also used as a gargle against dental caries and plaque formation (55). The antimicrobial activities of the hydro alcoholic extracts of the ginger and mallow were tested against the Listeria monocytogenesis, S. aureus, Methicillin resistant $S$. aureus and $P$. aeruginosa with the help of the micro plate dilution and disk diffusion method. The results showed the minimum inhibitory concentration (MIC) value in the range of 52 and 416 $\mu \mathrm{g} / \mathrm{ml}$ and the minimum bactericidal concentration $\mathrm{MBC}$ value in the range of 104 and $416 \mu \mathrm{g} / \mathrm{ml}$ and growth of inhibition zone in the range of 7-16 $\mathrm{mm}$ for the tested microbial strains against the hydro alcoholic extracts of the ginger. He observed that mallow had no antibacterial effects on these bacteria. Ginger extract is used as antibiotic in traditional medicine, microbiology and pharmacology sciences (54).

\section{Coriander}

Coriander belongs to the family Umbelliferae and mostly cultivated in India, Russia, Asia and Morocco. The ground seed of coriander has been used as spices. It was widely used to prepare chutney and sauces, cookies, buns, preparation of curry powder, pickling spices, seasoning and in food preservations (56). It is also used in the treatment of indigestion,

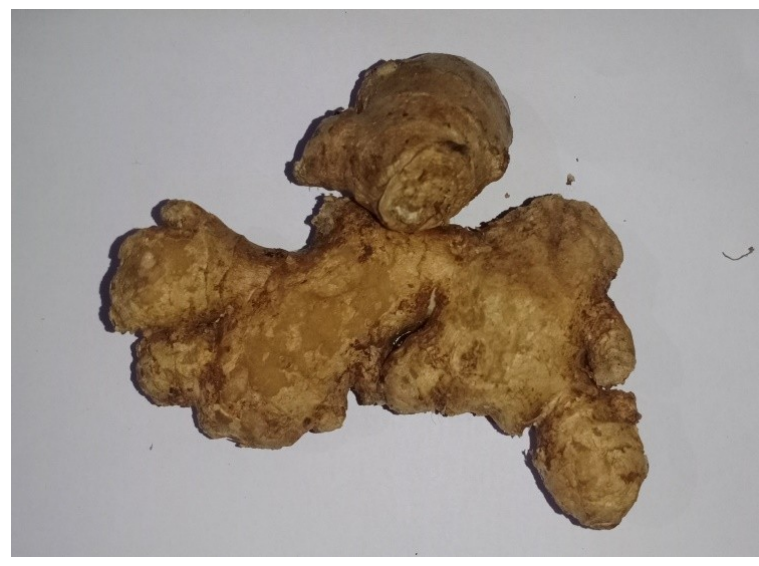

(a) Image of ginger

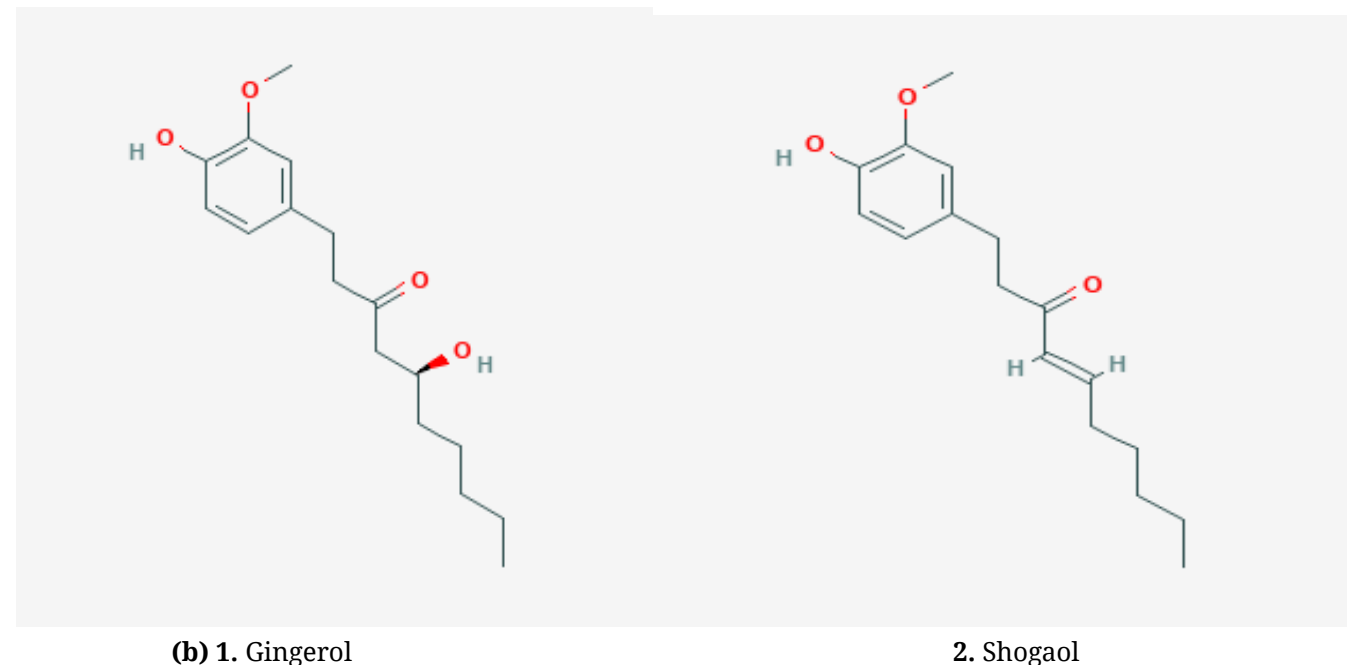

Fig. 5. (a) Image of ginger, (b) The Chemical structures of gingerol and shogaol presents in ginger (Source: 53). 
vomiting, rheumatism, diarrhea, dysentery and to treat pain in joints. The essential oil and other extract derived from coriander shows antibacterial, antimutagenic and antioxidant activities (57). Linalool is a major component found in coriander plant along with limonene, camphor and geraniol as shown in the Fig. 6. These components are responsible for the fragrance and aroma of the plant (58).

\section{Antimicrobial activities of coriander}

The antimicrobial activity of cinnamon, coriander and lemon was observed on various microbial strains through the agar dilution assay and vapor phase method. In the results it is observed that the coriander extract had exhibited the best anti-fungal activities in vapor phase. Also, it indicated that coriander had the antimicrobial properties at low concentration and on various strains displayed the minimum fungicidal concentration, minimum bactericidal concentration and minimum inhibitory concentration. In the result the MIC value was observed in the range between the $1-4 \mu / \mathrm{ml}$ (59). One more study investigated the antimicrobial activity of coriander against $E$. coli and Campylobacter jejuni microorganisms. The result shown the minimum inhibitory concentration of coriander against the tested microorganisms ranged between the $0.5-1 \mu \mathrm{L}$ per $\mathrm{mL}$ (60).

\section{Garlic}

It belongs to the family Amaryllidaceae. Garlic has been widely used as an agent for prevention and treatment of cardiovascular disease (24). It contains diallyl sulfide, allicin, alliin and ajoene as the major compounds as shown in Fig. 7. It helps to lower the blood pressure, prevent atherosclerosis, also it reduces the serum cholesterol, reduces the risk of common brain diseases like Alzheimer's disease and dementia. However, improper garlic use can result in side effects such as gastro intestinal upset and platelet dysfunction (62).

\section{Antimicrobial activity of garlic}

The antimicrobial activity of garlic against the $S$. aureus and $E$. coli was observed by using the agar diffusion method in the triplet's form. A factorial design with three factors was used. And data analysis was performed using mini tab statistical software package. The result represented that garlic extract have high range of anti-bacterial activity on all microorganisms. It shows the zone of inhibition in the range $>10 \mathrm{~mm}$. The compounds present in garlic are responsible for the antibacterial effect (24). When the antimicrobial activity of garlic was detected against pathogenic bacteria (B. subtilis, Aspergillus niger) by using the agar well diffusion method and it was observed

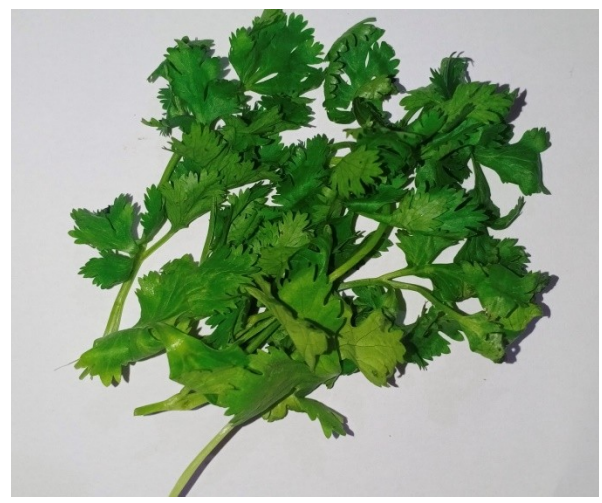

(a) Image of coriander

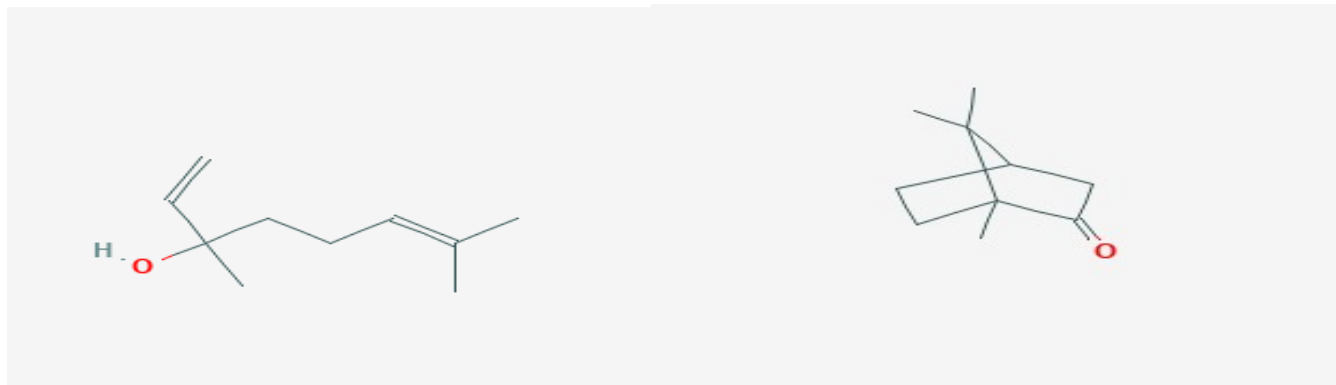

(b) 1. Linalool

2. Camphor

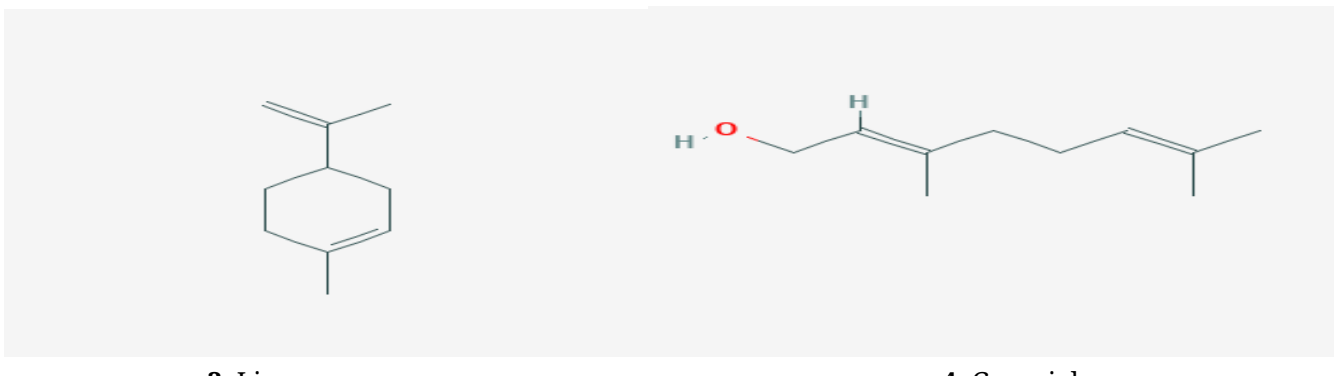

3. Limonene

4. Geraniol

Fig. 6. (a) Image of coriander, (b) The chemical structure of major compounds of the coriander (Source: 58). 
that the organic (thanol, methanol, ethyl acetate, chloroform, hexane, petroleum ether) extract of the leaves and bulb represents the highest antibacterial activity against a range of pathogens. Garlic extracts in ethyl acetate demonstrate more inhibition than extracts in chloroform, petroleum ether and hexane. The zone of inhibition was observed in the range between 2.0 to $12.0 \mathrm{~mm}$ (62).

\section{Antimicrobial activity of turmeric}

An antimicrobial activity of the turmeric methanol extract was tested on the $S$. aureus and results denoted that the plant extract was able to inhibit the growth of microorganisms at different concentrations and also reveals the genetic diversity of the strain. Therefore, it confirms that turmeric has an effective antibacterial activity against the $S$.

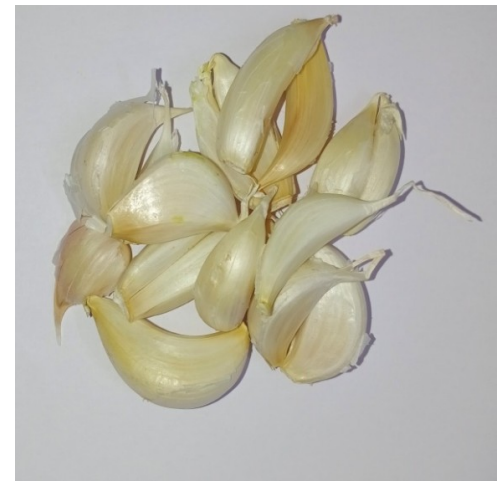

(a) Image of garlic

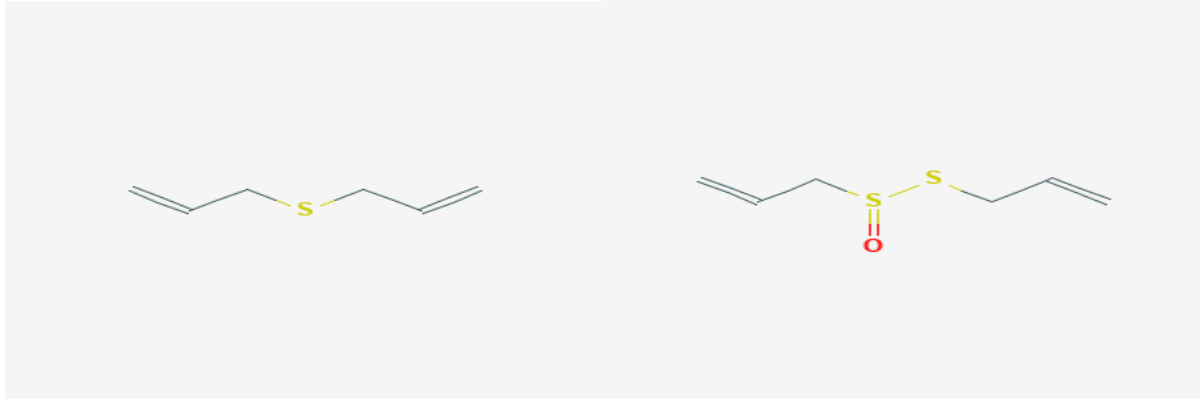

(b)1. Diallyl sulfide

2. Allicin

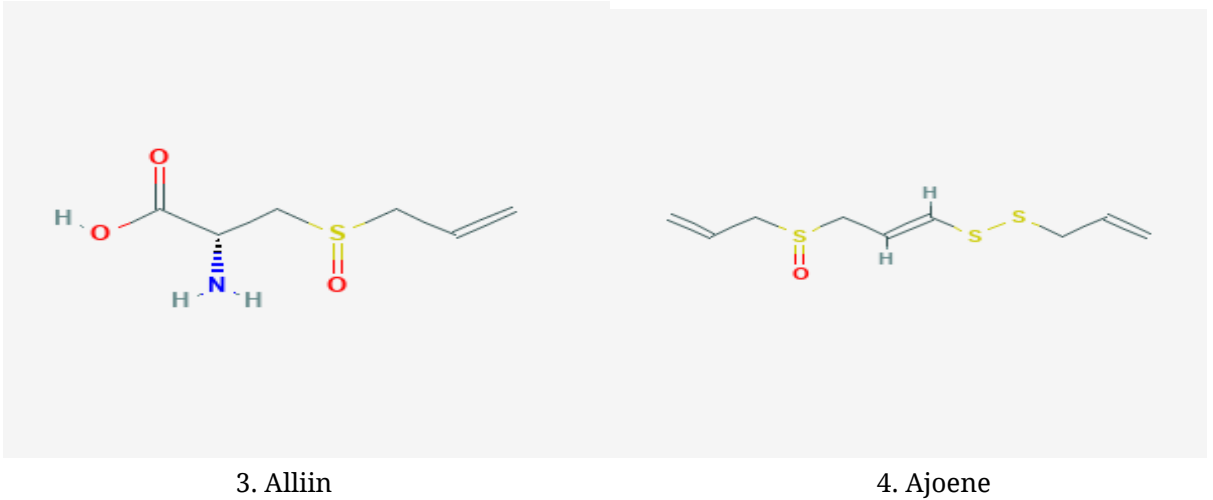

Fig. 7. (a) Image of garlic, (b) The chemical structures of the major components present in garlic (source: 61).

\section{Turmeric}

Curcuma longa or turmeric is member of Zingiberaceae family. It was commonly used in food for coloring and preservation. The Fig. 8 represents that it contains curcumin as the major compound. It has certain biological properties and used as an anti-inflammatory, wound-healing, anti-bacterial and anti-cancer agent (63). Also, it is used to treat wounds, parasitic skin infections, acne, cold, liver disease, urinary tract disease and also as a blood purifier. It is also used to relief the pain and bleeding in gingivitis and periodontitis (30). aureus (64). The antioxidant and antimicrobial activity of the ethanolic extracts of garlic, aloe, flower bud, turmeric and ginger were experimented in combination against the $S$. aureus, $P$. aeruginosa, $E$. coli and $B$. subtilis by using the well diffusion test and spectrophotometric test. The 2,2-diphenyl-1picrylhydrazylassay used to determine the antioxidant activity. Turmeric and ginger have higher antioxidant activity than the others (4). When the antibacterial activity of turmeric powder's was tested against Helicobacter pylori, then it found to have strong antibacterial activity against $H$. pylori. The extract was very effective in inhibition of the 


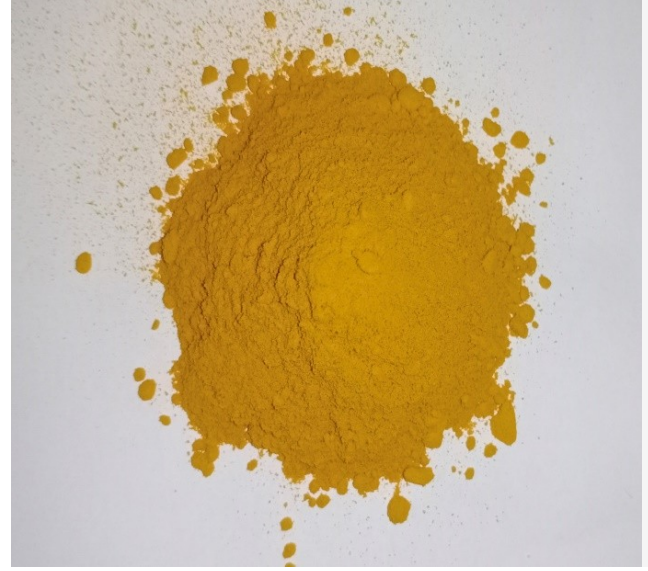

(a) Image of turmeric

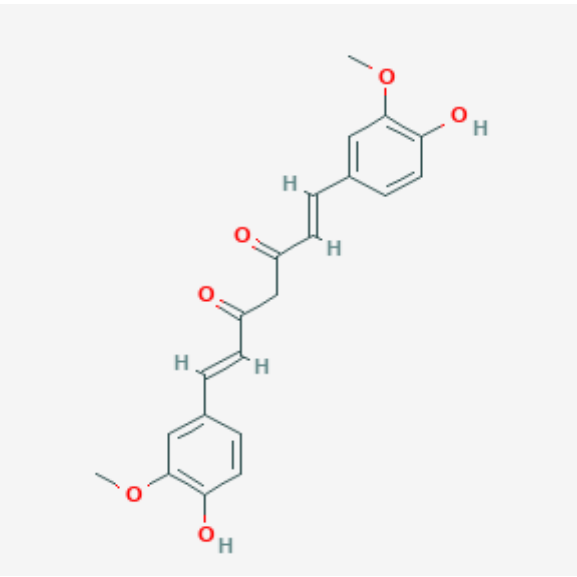

(b) Curcumin

Fig. 8. (a) Image of turmeric, (b) The major compound of Turmeric (source: 63).

bacteria and the zone of inhibition was recorded 7.7 mm (65).

\section{Mustard}

Mustard plant is a member of the Brassicaceae family. The different varieties of mustard are white or yellow mustard (Sinapis alba), brown mustard (Brassica juncea) and Black mustard (Brassica nigra). Mustard is an annual cold season plant that requires long days and short growing season (25). Mustard seeds are rich source of the energy, have $23-30 \%$ fixed oil, $29-36 \%$ protein and $12-18 \%$ carbohydrates. It contains geniposide and ginipin as major compounds as shown in Fig. 9. Mustard and mustard oil are used in treatment for rheumatism and arthritis, as a foot bath for the aching feet and in the form of plasters to treat the bronchitis and pneumonia. It has been also used as appetite stimulants, emetics and diuretics (66).

\section{Antimicrobial activity of mustard}

The antimicrobial activity of mustard seeds against the bacterial strains such as E. coli, P. aeruginosa and Candida albicans was studied with the help of the agar well diffusion methods and MIC determination by dilution method. The growth of inhibition zone was recorded in the range of $20-30 \mathrm{~mm}$. The findings show that a wide variety of antimicrobial properties can be obtained by preventing the growth of specific pathogens (66). When the antimicrobial activity of mustard seeds experimented against $S$. aureus, $B$. cereus, $P$. aeruginosa, Salmonella typhi and $E$. coli; the plant extract indicates a wide range of antimicrobial properties (78).

\section{Carom seeds}

Trachyspermum ammi is commonly termed as ajwain or thymol seeds. It belongs to the family Apiaceae and used as spice. The seeds of the plant are commonly used to prepare the biscuits, breads and other dishes (38). The ajwain seed contains antioxidants, vitamins, minerals and fiber. The Fig. 10 shows the chemical structures of thymol, $\gamma$ terpinene, arvacrol, limonene and $\beta$ - pinene; the major component present in ajwain. It is used for cleaning of the wounds and in treatment of the skin infections (69). Essential oil of ajwain is used in perfumes and toothpaste industry. It was also used to treat indigestion and gas relief, to treat the diarrhea and colic. It has germicidal and antifungal activity. It used for treating the post-natal disorders, menstrual disorder, itching and ringworm (70).

\section{Antimicrobial activity of Ajwain}

The inhibitory effect of ajwain essential oil was observed against the gram-positive bacteria such as $S$. aureus and gram-negative bacteria such as E. coli, Klebsiella pneumoniae. The Minimum inhibitory concentration (MIC) values were determined. The results showed the essential oil of ajwain has antimicrobial properties. For the bacterium $K$. pneumoniae MIC was $5 \mathrm{mg} / \mathrm{mL}$, for $E$. coli MIC 2.5 $\mathrm{mg} / \mathrm{mL}$ and for $S$. aureus MIC of $1.25 \mathrm{mg} / \mathrm{mL}$ respectively (70). The antimicrobial properties of ajwain seeds ethanolic extracts was experimented on different pathogenic bacteria such as $S$. aureus, Shigella, Salmonella typhi and E. coli. It was observed that ajwain seeds have high anti-oxidant and antimicrobial activity. Therefore, it can be used to enhance the shelf life of food products at room temperature. The growth of inhibition zone was observed between the range of 15-19 $\mathrm{mm}$ for both gram-positive and gram-negative bacteria (38).

\section{Black pepper}

Black pepper belongs to Piperaceae family. Originally it was cultivated in India. It has various medicinal values and used as spice. Also, it was used in medicine, as preservative and in perfumes (34). The plant needs moisture and hot place for the growth. It found in all tropical and subtropical area around the world (71). It contains piperene, limonene and caryophyllene as the major compound as shown in Fig. 11. The piperene has antispasmodic, antipyretic, antitumor, analgesic, antibacterial, antifungal, antibacterial, larvicidal, insecticidal and other activities (34). These components help for digestion as they stimulate the intestinal and pancreatic enzymes (72). In Thailand, the roots of the plant are used in various forms such as ghee, powders, enemas and balms. It is used to treat the abdominal tumor, headache, asthma, kidney stone, cold, cholera and 


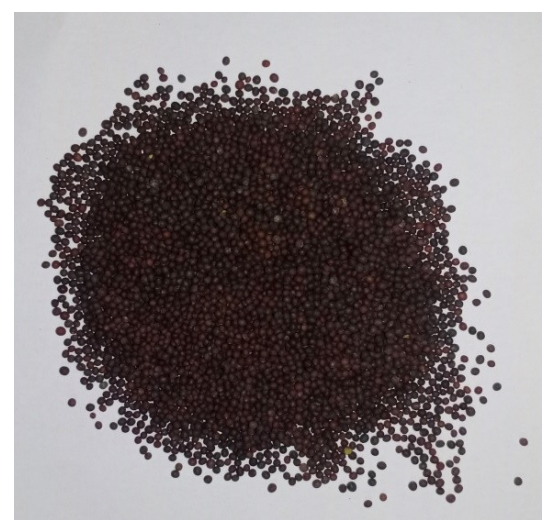

(a) Image of mustard seeds

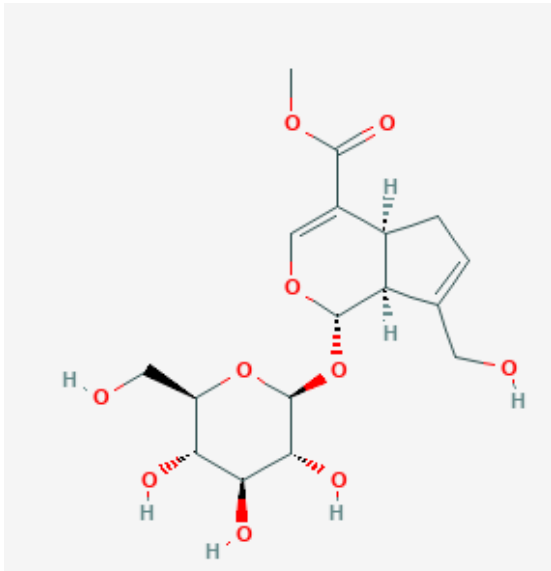

1. Geniposide

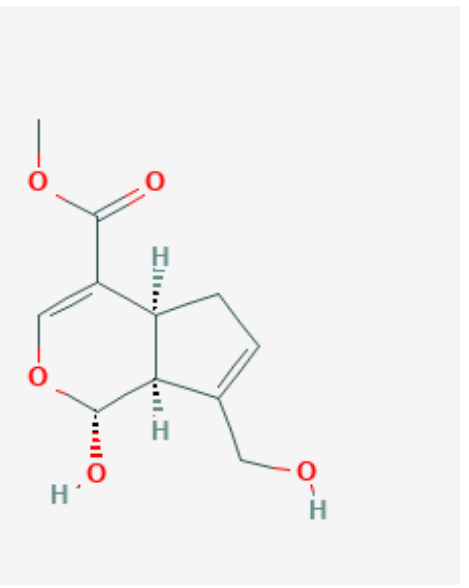

2. Ginipin

Fig. 9. (a) Image of mustard seeds, (b) The chemical structure of components of the mustard plant (source: 67).

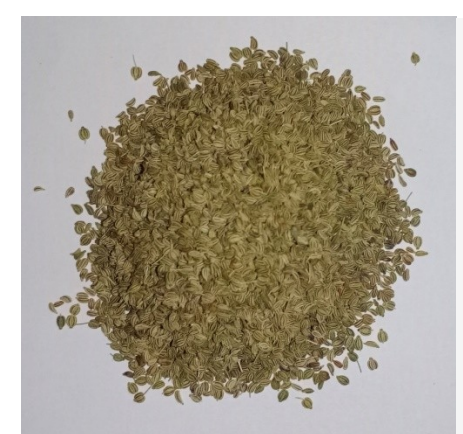

(a) Image of ajwain

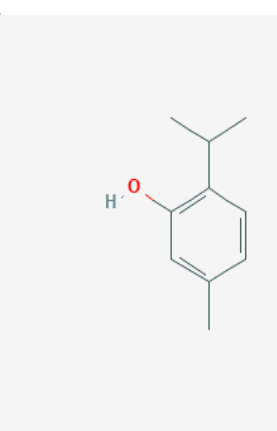

(b) 1 . Thymol
2. $\gamma$-terpinene

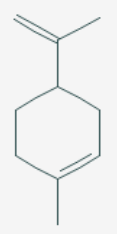

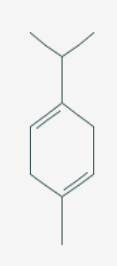

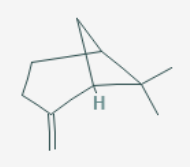
4. Limonene
5. $\beta$ - Pinene
3. Carvacrol

Fig. 10. (a) Image of ajwain, (b) The chemical structure of major compounds presents in ajwain (source: 69).

cancer. In ayurvedic medicines it was used to treat nasal congestion, sinusitis, epilepsy and skin inflammations (73).

\section{Antimicrobial activity of Black pepper}

Black pepper has antimicrobial properties due to the presence of phenolic compounds. Its mode of action 
includes attack on the bacterial membrane and thus restricts the growth of the bacteria. The antimicrobial properties of black pepper leaf extract were tested on the bacterial strains ( $P$. aeruginosa, $S$. typhimurium, $E$. coli, S. aureus) and fungal strains (C. albicans and Aspergillus sp.). The methanol extract exhibits antimicrobial and anti-fungal activity against the all strains (75). detected that cumin has good antibacterial activity against all the tested bacterial strains. Cumin extract and essential oil have been proposed as good sources of antimicrobial compounds against uropathogenic bacteria. For gram-positive uropathogenic bacteria MIC was observed in the range of the $0.015 \mathrm{mg} / \mathrm{mL}$ to $0.25 \mathrm{mg} / \mathrm{mL}$ and for gram-negative bacteria MIC was about $0.25 \mathrm{mg} / \mathrm{mL}$ (77).

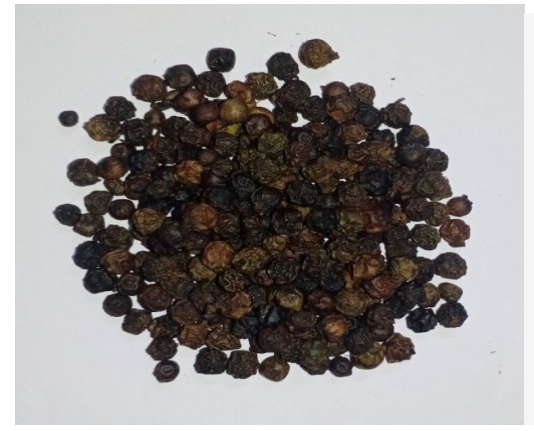

(a) Image of black pepper

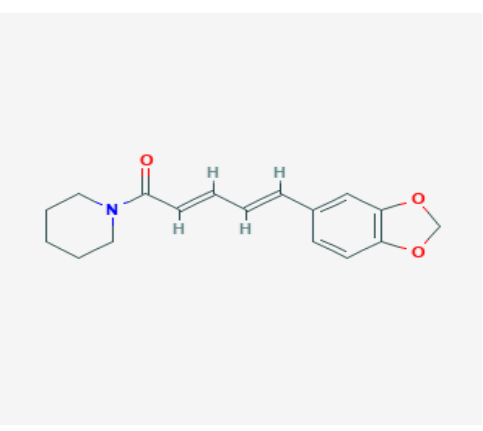

1. Piperine

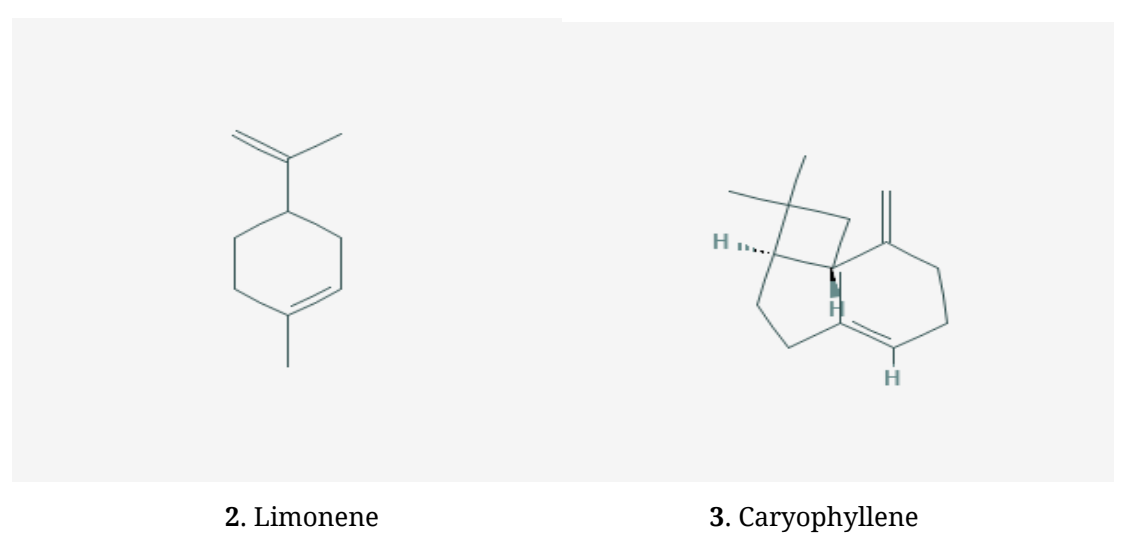

Fig. 11. (a) Image of black pepper, (b) The chemical structure of major Compounds of black pepper (source:74).

\section{Cumin}

It is the member of the Apiaceae family. It is commonly known as jeera. It is most widely used spice in India. It has carminative, stimulant, diuretic, emnanogogic and antispasmodic properties (27). It contains cuminal as a major component. It also contains alpha and $\beta$ pinene, $\beta$ myrcene and $\gamma-$ terpinene as shown in Fig. 12. All these components are responsible for medicinal and antimicrobial activities of the cumin (76).

\section{Antimicrobial activity of cumin}

The antimicrobial activity of the cumin extract on the numerous microbial strains such as $E$. coli, $P$. aeruginosa, $S$. aureus and Bacillus pumilus was experimented. Cumin extract was found to be effective against all of the tested bacterial strains. The growth inhibition zones observed with the help of agar well diffusion assay was found to be 10.7 to 14 $\mathrm{mm}$ diameter in the presence of cumin extract (27). When the antimicrobial activity of cumin extract and essential oil estimated against the $E$. coli, $K$. pneumoniae, $P$. aeruginosa, Streptococcus agalactiae, Enterococcus faecalis, Staphylococcus epidermidis, S. aureus and Staphylococcus saprophyticus. It was

\section{Noni}

It was member of family Rubiaceae. It contains methyl 4-hydroxycinnamate, methyl ferulate, methyl 4-hydroxybenzoate, p-hydroxy-cinnamic acid and ferulic acid as the major compounds as shown in Fig. 13 (80). Noni grows in the country of northern and central south America, Caribbean, India and Polynesia (11). It has antioxidant, antibacterial, antiinflammatory and anticarcinogenic properties. It has been used in pharmaceutical industries for preservation (81).

\section{Antimicrobial activity of noni}

The antibacterial activity of noni extracts was detected against the $L$. monocytogenes by using the disc diffusion method. The findings show that it has potent antibacterial activity against the bacterial strain and can be used as a natural sanitizer. The zone of growth inhibition was in the range of $15-22$ $\mathrm{mm}$ (81). The antibacterial activity of noni extracts against the Enterobacter aerogenes, Klebsiella oxytoca, E. coli, B. cereus and $P$. aeruginosa was examined. It has good antibacterial activity against $B$. 


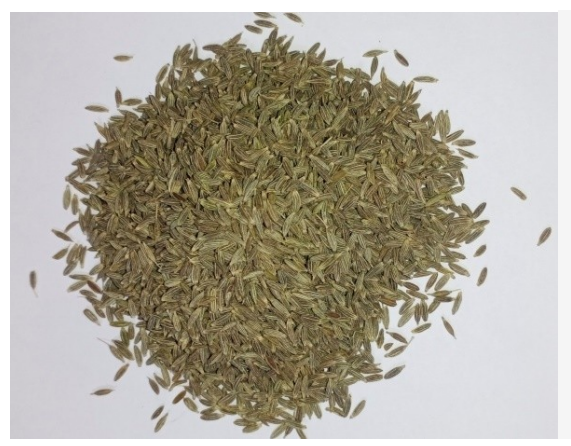

(a) Image of cumin

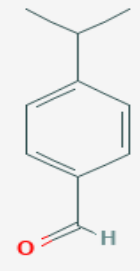

(b) 1. Cuminal
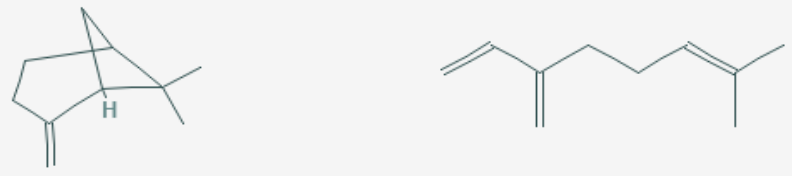

4. $\gamma$-terpinene

Fig. 12. (a) Image of cumin, (b) The chemical structure of major compounds presents in cumin (source: 76).

cereus and $P$. aeruginosa bacterial strains as confirmed by the findings (82).

\section{Wintergreen}

Wintergreen belongs to the family of Ericaceae. Its oil is used in cosmetics, foods and pesticides. It has been used for relieving the nerve and muscle pains. It has been used in mouthwash and toothpaste (83). Mainly it is cultivated in northeastern north America. It has antipyretic, analgesic and anti-inflammatory properties. It has been used to treat the wounds, rheumatoid arthritis, asthma and cough (84). It

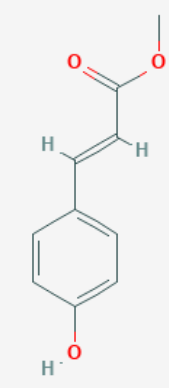

1.Methyl 4-hydroxycinnamate

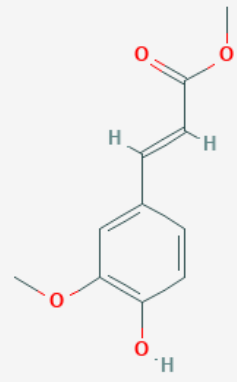

2. Methyl ferulate

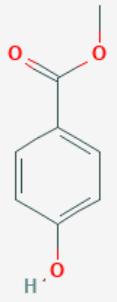

3. Methyl 4-hydroxybenzoate<smiles>O=C(O)C=Cc1ccc(O)cc1</smiles>

4.p-hydroxy-cinnamic acid

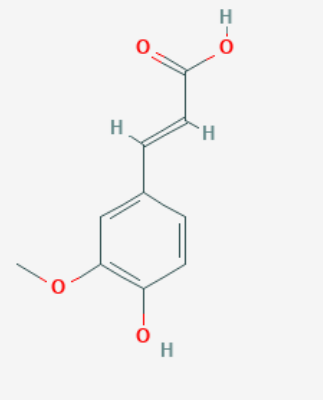

5. Ferulic acid.

Fig. 13. The chemical structure of major compounds of noni (source: 80). 
contains methyl salicylate and linalool as major compounds as shown in Fig. 14.

\section{Antimicrobial activity of wintergreen}

The antibacterial activity of essential oil of wintergreen was tested against $S$. aureus, $E$. coli and $A$. baumannii by observing the minimum inhibitory concentration and microdilution test. In the results it represents that wintergreen extracts oil rich in methyl salicylate which has strong antibacterial activity. For gram-negative bacteria MIC was recorded in range between $8.2-10 \mathrm{mg} / \mathrm{mL}$ and grampositive bacteria showed the MIC range between 13.5-16.7 mg/mL (84).

\section{Sage}

It belongs to the family of Lamiaceae. Sage extracts has antioxidant, antifungal, antiviral and antibacterial properties. It has been used in the treatment of oral problems, for the treatment of dyspepsia, skin and throat inflammation, cognitive disorders (85). It is cultivated in north America and European countries (12). As shown in the Fig. 15, it contains $\beta$-pinene, camphene, borneol and a-pinene as the major compounds (86).
Plant parts are used in the preparation of recipes and mostly leaves, root, bark, petiole, stem and fruits are used. They are also used in the form of powder, maceration, ash, fumigation and trituration. The leaves of Orthosiphon stamineus are used as herbal tea to treat diuresis, to treat rheumatoid arthritis, diabetes, oedema, eruptive fever, influenza, hepatitis, jaundice and hypertension. In different industries the contribution of plants is remarkable such as fine chemicals, cosmetics, industrial raw materials, pharmaceuticals and drugs etc. The serpentine compound present in Rauwolfia serpentina is used in the treatment of hypertension and lowering of blood pressure (89). The drug, Vinblastine isolated from the Catharanthus roseus is used for the treatment of leukemia in children, hodgkins choriocarinoma, nonhodgkins lymphomas, testicular and neck cancer. Medicinal plants played an important role in the creation of human society and due to various beliefs used in various ceremonies in different cultures (88). Medicinal plants have been increased the waves of interest in the field of research in natural product chemistry because of the therapeutic needs due to the remarkable diversity of both chemical structure and biological activities of naturally occurring secondary

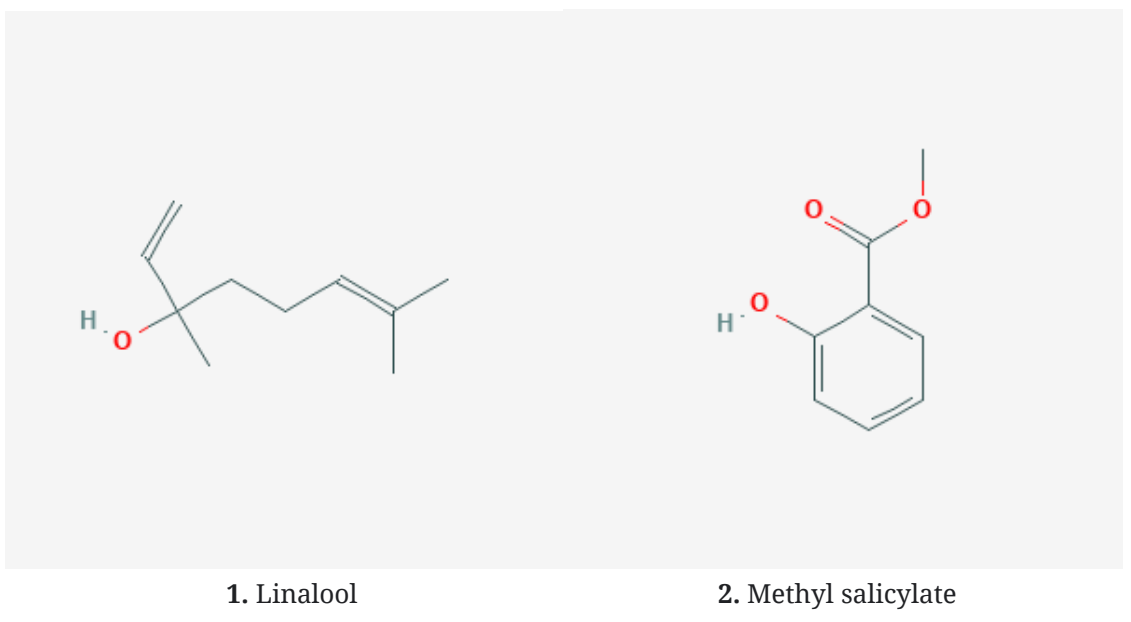

Fig. 14. The chemical structure of major compounds of wintergreen (source: 83).

\section{Antimicrobial activity of sage}

The antimicrobial activity of sage extract oil was investigated against the Pseudomonas luteola, E. faecalis, Vibrio vulnificus, S. aureus, S. paratyphi and $K$. pneumonia with the help of gas chromatographymass spectrometry, disc diffusion method, minimum inhibitory concentration and minimum bactericidal concentration method. According to the findings, it was observed that sage essential oil had potent antimicrobial activity against all microorganisms. It showed the zone of growth inhibition in the range of $12 \mathrm{~mm}$ to $19 \mathrm{~mm}$ (86). The disc diffusion assay was used to test the antimicrobial activity of sage extract against E. coli, Pasteurella canis, Plesiomonas shigelloides, $K$. pneumoniae and Dermatophilus congolensis. The findings show that it has potent antimicrobial activity against the other bacterial strain except $D$. congolensis. In disc diffusion method, others strains show the $10-12 \mathrm{~mm}$ zone of growth inhibition and $D$. congolensis shows only narrow zone around $8 \mathrm{~mm}$ of growth inhibition (87). metabolites present in a wide variety of plant species (90). The medicinal spices plants are used to treat neurological diseases such as epilepsy, headache, migraine and psychiatric diseases which includes symptoms like madness, hallucination and mental disorder. These plants also have sedative, tranquilizing, psychoactive effects and also used to treat insomnia (91).

\section{Conclusion}

The antimicrobial agents are very necessary to decrease the load of contagious disease. Although the emergence and spread of the MDR (Multiple Drug Resistant) strain in the pathogens is a significant threat as community strength, since there are few or null side effects of antimicrobial agents for infections that are often caused by pathogens or infectious diseases. Plants consists the chemical substances that affect the human body; such as alkaloids, flavonoids, terpenoids, steroids, carotenoids and other phenolic 

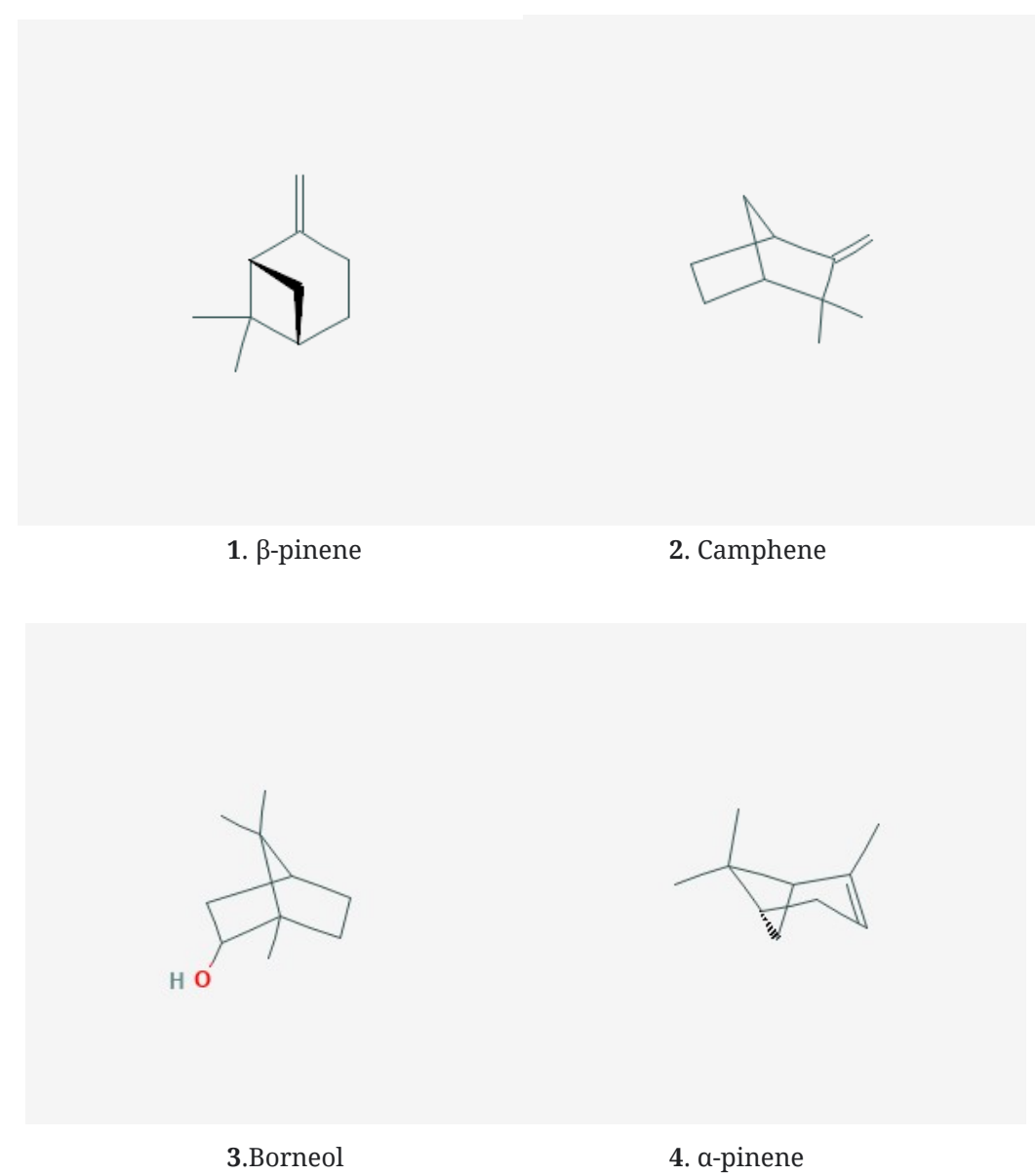

Fig. 15. The chemical structure of major compounds of sage (source: 86).

compounds etc. These substances play a major role in traditional medicine. Therefore, in different countries various medicinal plants are used to produce effective and powerful drugs. The medicinal plants are used to extract the raw drugs and they possess variable medicinal properties. Thus, the research is to discover the advance form of actual medicine and to found new medicine purpose. In the new studies, the significant sources of human medicines are tested by using synthetic chemical reactions, combinational chemistry and cell modelling derived components to drug discovery. Several research studies proved that the ethno plants have the medicinal and pharmacological activity. The majority of plants used in ethnic medicine have been recorded for their antimicrobial properties against pathogens. Traditional medicine encompasses all of the knowledge, skills and activities based on the hypotheses, convictions and experiences of indigenous peoples from various cultures, whether rational or not, and is used to help health-care services, as well as to identify, avoid, improve and manage physical and psychological instability. Numerous traditional systems of medicines are practised around the world with several related beliefs and social causes. Recently COVID-19 infection is declared by the WHO as a global pandemic. It was a tremendously infectious disease. It was caused by SARS-CoV-2 virus. Apart from the other food source, medicinal plants are very important sources of the medicines to combat COVID-19 infection and the respiratory diseases are treated from the ages by the use of medicinal plants. It serves the effective medicine to treat the infection due to their antipyretic, antioxidant, anti-inflammatory, antiviral, cyto-protective and immunomodulatory properties.

\section{Future prospective}

The problem with natural antimicrobial agents is that many factors, such as maximum plasma concentration and tissue penetration can impair their efficacy. However, further research is being done to understand the antimicrobial function of other plants and to determine their exact mechanism of action. As a result, in the coming years, people could place a greater emphasis on herbal-based medicines due to their medicinal properties and less or no side effects. More medicinal spice plants and their extracts should be included in people's diet to keep them safe and free of infection.

\section{Novelty of work}

The main goal of this literature review is to learn more about different plants' antimicrobial activity against human pathogens. We've also discussed about the secondary metabolite compounds present in these plants that have antioxidant, antifungal and antimicrobial properties. It makes them an excellent option for treating common infections and diseases mentioned in this article. A variety of publications on the medicinal spice plant have been referred. They focused on the antimicrobial activity of specific plants, while this study collects information on a broad range of plants, the essential antimicrobial 
compounds found in them and their efficacy in treating various diseases as well as their use to preserve various foods, parallel use in the pharmaceutical industry.

\section{Acknowledgements}

The authors would like to express their gratitude to their respective institution for the support and encouragement.

\section{Authors' contributions}

VMM searched, collected, and wrote the first draft. NP analyzed the manuscript, provided the regular assistance to revise and finalize it. NP along with HA review and edited the manuscript. AA critically reviewed and edited the same. All authors have read and approved to publish the manuscript.

\section{Conflict of interests}

There are no conflicts of interest declared by the authors.

\section{References}

1. Amenu D. Antimicrobial activity of medicinal plant extracts and their synergistic effect on some selected pathogens. A J Ethno. 2014;1:1:18-19.

2. Manandhar S, Luitel S, Dahal RK. In vitro antimicrobial activity of some medicinal plants against human pathogenic bacteria. Trop Med. 2019;2019:1895340:1-5. https://doi.org/10.1155/2019/1895340

3. Ali A. Herbs that heal: The philanthropic behavior of nature. Ann Phytomed. 2020;9(1):7-17. http://dx.doi.org/10.21276/ap.2020.9.1.2

4. Kumar A, Sharma P, Mahajan A, Begum Z. In vitro comparative study of antioxidant and antibacterial activity of selected dietary plants. Nepal J Biotechnol. 2018;6:1:39-45. https://doi.org/10.3126/njb.v6i1.22336

5. Shrivastava AK, Chaurasiya JP, Khan R, Dhand C, Verma S. Role of medicinal plants of traditional use in recuperating devastating COVID- 19 situation. J Med Aromat Plants. 2020; 9:5:1-16. https://doi.org/10.35248/2167-0412.20.9.359

6. Subhose V, Srinivas P, Narayana A. Basic principle of pharmaceutical science in Ayurveda. Institute of History of Medicine. 2005;35:2:83-92.

7. Hassan, Ullah H. Antibacterial and antifungal activities of the medicinal plant Veronica biloba. J Chem. 2019;2019: 5264943:17. https://doi.org/10.1155/2019/5264943

8. Mahato T K, Sharma K. Study of medicinal herbs and its antibacterial activity: a review. J Drug Deliv Ther. 2018;8:5S:47-54. https://doi.org/10.22270/jddt.v8i5-s.1938

9. Khan T, Khan MA, Mashwani ZR, Ullah N, Nadhman A. Therapeutic potential of medicinal plants against COVID-19: the role of antiviral medicinal metabolites. Biocatal Agric Biotechnol. https://doi.org/10.1016/j.bcab.2020.101890

10. Ganapathy S, Dakappa SS, Lakshmikantha RY. Antibacterial and molecular docking studies of bioactive component from leaves of Stachytarpheta cayennensis (Rich.) Vahl Res J Phytochem. https://dx.doi.org/10.3923/rjphyto.2017.28.34

$2016 ; 11: 1: 28-43$

11. Blanco YC, Vaillant F, Perez AM, Reynes M, Brillouet JM, Brat P. The Noni Fruit (Morinda citrifolia L.): A Review of agricultural research, nutritional and therapeutic properties. Journal of Food Composition and Analysis. 2006;19(6-7):645-654. https://doi.org/10.1016/j.jfca.2005.10.001

12. Ghorbani A, Esmaeilizadeh M. Pharmacological properties of Salvia officinalis and its components. Journal of Traditional and Complementary Medicine. 2017;7(4):433-40. https://dx.doi.org/10.1016\%2Fj.jtcme.2016.12.014

13. Saxena M, Saxena J, Nerma R, Singh D, Gupta A Phytochemistry of medicinal plants. J Pharmacogn Phytochem. 2013;1(6):168-82.

14. Dhiman $\mathrm{R}$, Aggarawal $\mathrm{N}$, Aneja $\mathrm{KR}$, Kaur $\mathrm{M}$. In vitro antimicrobial activity of spices and medicinal herbs against selected microbes associated with juices. Int J Microbiol. 2016:9015802. https://doi.org/10.1155/2016/9015802

15. Gottardi D, Bukvicki D, Prasad S, Tyagi AK. Beneficial effects of spices in food preservation and safety. Front Microbiol.2016;7: 1394. https://doi.org/10.3389/fmicb.2016.01394

16. Kia FJ, Lorigooini Z, Khoei HA. Medicinal plants: past history and future perspective. J Herb Med Pharmacol. 2017;7(1):1-7. https://doi.org/10.15171/jhp.2018.01

17. Wiart C. Enthnopharmacology of medicinal plants: Asia and the Pacific. Br J Clin Pharmacol. 2007;64(6):750-57. https://dx.doi.org/10.1111\%2Fj.1365-2125.2007.02888.x

18. Petrovska BB. Historical review of medicinal plants usage. Pharmacognosy. 2012;6(11):1-5. http://dx.doi.org/10.4103/09737847.95849

19. Silver LL. Are natural products still the best source for antibacterial discovery? the bacterial entry factor. Drug Discov. https://doi.org/10.1517/17460441.3.5.487 2008;3(5):487-500.

20. Adhikari P, Paul SB. History of Indian traditional medicine: A Medical Inheritance. Asian J Pharm Clin. Res. 2018;11(1):421 26. https://doi.org/10.22159/ajpcr.2018.v11i1.21893

21. Ahmed BE, khan J, Sajjad N, Ali A, Aldakeel FM, Mateen A, Alqahtani MS, Rabbani S. SARS-CoV-2: Insight in genome structure, pathogenesis and viral receptor binding analysisAn Updated Review. Int Immuno Pharmacol. 2021;95:107493. https://doi.org/10.1016/j.intimp.2021.107493

22. Yabesh M, Vijaykumar S, Arulmozhi P, Rajalakshmi S Screening the antimicrobial potential of twelve medicinal plants against venereal diseases causing pathogens. Acta Ecologica Sinica. 2019;39(5):356-61, https://doi.org/10.1016/j.chnaes.2018.09.011

23. Elizabeth J, Gassara F, Kouassi AP, Brar SK, Belkacemi K. Spice use in food: properties and benefits. Crit Rev Food Sci Nutr. 2017;(57(6):1078-88 https://doi.org/10.1080/10408398.2013.858235

24. Wolde T, Kuma H, TruehaK, Yabeker A. Anti-bacterial activity of garlic extract against human pathogenic bacteria. Pharmacovig. 2018;6(1):1-5. https://doi.org/10.4172/23296887.1000253

25. Fahmi R. Antioxidant and antibacterial properties of endogenous phenolic compounds from commercial mustard products. 2016; Master's Thesis; University of Manitoba, Winnipeg, Canada. http://hdl.handle.net/1993/31624

26. Miceli A, Aleo A, Corona O, Sardina MT, Mammina C, Settanni L. Antibacterial activity of Borago officinalis and Brassica juncea aqueous extracts evaluated in vitro and in situ using different food model systems. Food Cont. 2014;40:157-64. http://dx.doi.org/10.1016/j.foodcont.2013.12.006

27. Dua A, Garg G, Balkar S, Mahajan R. Antimicrobial properties of mentholic extract of cumin (Cuminum cyminum) seeds. Int Res Ayurveda Pharm. 2013;4(1):104-07. http://dx.doi.org/10.7897/2277-4343.04136

28. Shreaz S, Wani WA, Behbehani JM, Raja V, Irshad M, Karched M, Ali I, Siddiqi WA. cinnamaldehyde and its derivatives, A novel class of antifungal agents. Fitoterapia. 2016;112:116-31 https://doi.org/10.1016/j.fitote.2016.05.016

29. Mageed MA, Mansour AF, Massry KF, Ramadan MM, Shaheen MS, Shaaban H. effect of microwaves on essential oils of coriander and cumin seeds and on their antioxidant and 
antimicrobial activities. J Essent Oil-Bear Plants. 2012; 15(4):614-27. https://doi.org/10.1080/0972060X.2012.10644096

30. Pillay SR, Roy A, Rajeshkumar S, Lakshmi T. Antimicrobial activity of turmeric, cumin, and ginger oil on oral pathogens. Drug Invent Today. 2019;11(5):1106-09.

31. Mahendra P, Bisht S. Ferula asafoetida: Traditional uses and pharmacological activity. Pharmacogn Rev. 2012;6(12):141-46. https://doi.org/10.4103/0973-7847.99948

32. Dusica P, Nikolic LB. Improvement of the yield and antimicrobial activity fennel (Foeniculum vulgare Mill.) essential oil by fruit milling. Ind crops Prod. 2019;142(1):7. https://doi.org/10.1016/j.indcrop.2019.111854

33. Shaharajabian MH, Sun W, Cheng Q. Chinese Star Anise and Anise, magic herbs in traditional chinese medicine and modern pharmaceutical science. Asian J Med Biol Res. 2019; 5(3):162-79. https://doi.org/10.3329/ajmbr.v5i3.43584

34. Salehi B, Zakaria ZA, Gyawali R, Ibrahim SA, Rajkovic J, Shinwari Z K, Khan T. Piper Species: a comprehensive review on their phytochemistry, biological activities and applications. Molecules.

https://doi.org/10.3390/molecules24071364

35. Vangara A, Babitha GA, Prakash S, Timmasetty J. Evaluation of antibacterial efficacy of sesame seed on periodontal pathogens: an in vitro study. CODS J Dent. 2019;11(2):44-47. https://doi.org/10.5005/jp-journals-10063-0048

36. Burt S. Essential Oils: Their antibacterial properties and potential applications in foods-A Review. Int J Food Microbiol. https://doi.org/10.1016/j.ijfoodmicro.2004.03.022

37. Timimi LN. Antibacterial and anticancer activities of fenugreek seed extract. Asian Pac J Cancer. 2019;20(12):377176. https://dx.doi.org/10.31557/APJCP.2019.20.12.3771

38. Bhatt V, Kumar M, Selvam P. Antimicrobial effect of ajwain seed ethanolic extract against food borne pathogenic bacteria. Int Food Res J. 2018; 25(3):908-12.

39. Srilaong V, Tanprasert K, Kalaynarat S, Nguanpuag KS, Techavuthiporn C. Ginger (Zingiber officinale) oil as an antimicrobial agent for minimally processed produce: A case study in Shreddedgreen Papaya. Int J Agric Biol. 2011;13(6):895901. https://doi.org10-702/dnt/2011/13-6-895-901

40. Nunez L, Aquino MD. Microbicide activity of clove essential oil (Eugenia caryophyllata). Braz J Microbiol. 2012;43(4):1255-60. https://doi.org/10.1590/S1517-83822012000400003

41. Xu JG, Liu T, Hu QP, CaoXM. Chemical composition, antibacterial properties and mechanism of action of essential oil from clove buds against Staphylococcus aureus. Molecules. 2016;21(9):1194. https://doi.org/10.3390/molecules21091194

42. Mbaveng AT, Kuete V. Syzygium aromaticum in medicinal spices and vegetables from Africa. Academic Press. 2017;61125. http://dx.doi.org/10.1016/B978-0-12-809286-6.00029-7

43. Pandey A, Singh P. antibacterial activity of Syzygium aromaticum (clove) with metal ion effect against food borne pathogens. Asian J Plant Sci Res. 2011;1(2):69-80.

44. Badei A, Faheld S, Akel E, Mahmoud B. Application of some spices in flavoring and preservation of cookies: 2-antimicrobial and sensory properties of cardamom, cinnamon and clove. DtschLebensmRundsch. 2002;98:261-65.

45. Zhang H, Chen X, He JJ. Pharmacological action of clove oil and its application in oral care products. Oral Care Industry. 2009;19:23- 24.

46. Coccimiglio J, Alipour M, Jiang ZH, Gottardo C, Suntres Z. Antioxidant, antibacterial and cytotoxic activities of the ethanolic Origanum vulgare extract and its major constituents. Oxid Med Cell Longev. 2016:1404505. https://doi.org/10.1155/2016/1404505

47. Veenstra JP, Johnson JJ. Oregano (Origanum vulgare) extract for food preservation and improvement in gastrointestinal health. Int J Nutr. 2019;3:43-52. https://doi.org/10.14302/issn.2379-7835.ijn-19-2703

48. Liu Q, Meng X, Li Y, Tang GY. Antibacterial and antifungal activities of spices. Int J Mol Sci. 2017;18(6):1283. https://doi.org/10.3390/ijms18061283
49. Keith S. Cinnamon: Update of Potential Health Benefits. Nutrition Today. 2019;54(1):42-52. http://dx.doi.org/10.1097/NT.0000000000000319

50. Rao PV, Gan SH. Cinnamon: A Multifaceted Medicinal Plant. Evid Based Complement Alternat Med. 2014; 2014:642942. https://doi.org/10.1155/2014/642942

51. Wang Q, Ou ZB, Lei HW, Zeng XH, Ying Y, Bai WD. Antimicrobial activities of a new formula of spice water extracts against foodborne bacteria. J Food Process Preserv. 2012;36(4):374-81. 4549.2012.00691.x https://doi.org/10.1111/j.1745

52. Revati S, Bipin C, Chitra P, Minakshi B. In vitro antibacterial activity of seven Indian spices against high level gentamicin resistant strains of Enterococci. Arch Med Sci. 2015;11(4):863 68. https://doi.org/10.5114/aoms.2015.53307

53. Semwal RB, Semwal DK, Combrick S, Viljoen AM. Gingerol and shogoal: important nutraceutical principles from ginger. Phytochem. 2015;117:554-68. https://doi.org/10.1016/j.phytochem.2015.07.012

54. Azadpour M, Azadpour N, Bahmani M, Hassanzadazar H, Kopaei MR, Naghdi N. Antimicrobial effect of ginger (Zingiber officinale) and Mallow (Malva sylvestris) hydroalcoholic extracts on four pathogen bacteria. Der Pharmacia Letter. 2016;8(1):181-87.

55. Mostafa NM. Antibacterial activity of ginger (Zingiber officinale) leaves essential oil nanoemulsion against the Cariogenic Streptococcus mutans. J Appl Pharm Sci. 2018; 8(9):34-41. https://doi.org/10.7324/japs.2018.8906

56. Silva F, Domingues FC. Antimicrobial activity of coriander oil and its effectiveness as food preservative. Crit Rev Food Sci Nutr. https://doi.org/10.1080/10408398.2013.847818

2017;57(1):35-47.

57. Dua A, Garg G, Kumar D, Mahajan R. Polyphenolic composition and antimicrobial potential of methanolic coriander (Coriandrum sativum) seed extract. Int J Pharm Sci. 2014;230208. http://dx.doi.org/10.13040/IJPSR.0975-8232.5(6).2302-08

58. Onder A. Coriander and its phyto constituents for the beneficial effects. Potential of Essential Oil. 2018;165-85. http://dx.doi.org/10.5772/intechopen.78656

59. Dimic G, Tanackov SK, Mojovic L, Pejin J. Antifungal activity of lemon essential oil, coriander and cinnamon extracts on food borne molds in direct contact and the vapor phase. J Food $\begin{array}{lll}\text { Process } & \text { Pres. 2015;39(6):1778-87. }\end{array}$ https://doi.org/10.1111/jfpp.12410

60. Duarte A, Ferreira S, Silva F, Domingues FC. Synergistic activity of coriander oil and conventional antibiotics against Acinetobacter baumannii. Phytomedicine. 15;19(3-4):236-38. https://doi.org/10.1016/j.phymed.2011.11.010

61. Shang A, Cao SY, Xu XY, Gan RY, Tang GY. Bioactive compounds and biological functions of garlic (Allium sativum L.). Foods. 2019;8(7):246. https://doi.org/10.3390/foods 8070246

62. Gunda MM, Rajendra PB, Odelu G, Ugandhar T. Studies on antimicrobial activity of garlic extract against Bacillus subtilis and Aspergillus niger. Int J Curr Adv Res. 2018;7(1):9169-71. http://dx.doi.org/10.24327/ijcar.2018

63. Banik U, Parasuraman S, Adhikari AK, Othman NH. Curcumin: The spicy modulator of breast carcinogenesis. J Exp Clin Cancer Res. 2017;36:98. https://doi.org/10.1186/s13046-017 0566-5

64. Feghali PAR, Ibrahim R, Nawas T. Antibacterial activity of curcumin against lebanese clinical isolates of Staphylococcus aureus. Moj Toxicology. 2018;4(2):81-83. https://doi.org/10.15406/mojt.2018.04.00094

65. Ali N. In vitro studies of antimicrobial Activity of (Curcuma longa) rhizomes against Helicobacter pylori. Iraq Medical Journal. 2017;1(1):7-9.

66. Tomar RS, Shrivastava V. Efficacy evaluation of ethanolic extract of Brassica nigra as potential antimicrobial agen against selected microorganism. Int J Pharm Healthc Mark. 2014;3(4):117-23.

67. Peng C, Zhao SQ, Zhang J, Huang GY, Chen LY, Zhao FY. Chemical composition, antimicrobial property and 
microencapsulation of mustard (Sinapis alba) seed essential oil by complex coacervation. Food Chemistry. 2014;165:560-68. https://doi.org/10.1016/j.foodchem.2014.05.126

68. Lu M, Dai T, Murray CK, Wu MX. Bactericidal property of oregano oil against multidrug resistant clinical isolates. Front Microbiol. https://doi.org/10.3389/fmicb.2018.02329 2018;9:1-14

69. Chahal K, Dhaiwal K, Single N. Chemical composition of Trachyspermum ammi L. and it's biological properties: A Review. J Pharmacogn Phytochem. 2017;6(3):131-40.

70. Mood BS, Shafeghat M, Metanat M, Saeidi S, Sepehri N. The inhibitory effect of ajwain essential oil on bacterial growth. Int J Infect. 2014;1(2):e19394. https://dx.doi.org/10.17795/iji-19394

71. Li Z, Liu A, Wu H, Tan L, Long Y, Gou Y, Sun S, Sang L. Influence of temperature, light and plant growth regulators on germination of black pepper (Piper nigrum L.) Seeds. Afr J Biotechnol.

https://doi.org/10.5897/AJB10.1571f

2010;9(9):1354-58.

72. Zhu F, Mojel R, Li G. Physicochemical properties of black pepper (Piper nigrum) starch. Carbohydr Polym. 2018;181:98693. https://doi.org/10.1016/j.carbpol.2017.11.051

73. Fern K, Fern A, Morris R. Useful Tropical Plants Database. 2019. http://tropical.theferns.info/viewtropical.php? id=Calopogonium $\% 20$ caeruleum

74. Lomarat $\mathrm{P}$, Sripha $\mathrm{K}$, Phanthong $\mathrm{P}$, Kitphati $\mathrm{W}$. In vitro biological activities of black pepper essential oil and its major components relevant to the prevention of Alzheimer's disease. Thai J Pharm Sci. 2015;39(3):94-101.

75. Akthar MS, Birhanu G, Demise S. antimicrobial activity of Piper nigrum and Cassia didymobotyra leaf extract on selected food borne pathogens. Asian Pac J Trop Dis. 2014;4(2):S911-S919. https://doi.org/10.1016/S2222-1808(14)60757-X

76. Amin G. Cumin. Handbook of herbs and spices. 2012;250-59. https://doi.org/10.1533/9780857095671.250

77. Saee Y, Dadashi M, Eslami G, Goudarzi H, Taheri S, Fallah F. Evaluation of antimicrobial activity of Cuminum cyminum essential oil and extract against bacterial strains isolated from patients with symptomatic urinary tract infection. Novelty in Biomedicine. https://doi.org/10.22037/nbm.v4i4.9867

2016;44:147-52.

78. Ogidi OI, George DG, Enenebeaku UE, Esie NG, Akpan UM. Efficacy evaluation of extracts of Brassica juncea (Brown mustard) seeds as potential antimicrobial agent against pathogenic microbes. J Med Plants Stud. 2019;7(4):263-65.

79. Nugraha RV, Ridwansyah H, Ghozali M, Khairani AF, Atik N. Traditional herbal medicine candidates as complementary treatments for COVID-19: A review of their mechanisms, pros and cons, evidence-based complementary and alternative medicine. Evid Based Complement Alternat Med. 2020; 2020:2560645. https://doi.org/10.1155/2020/2560645

80. Zhang WM, Wang W, Zhang JJ, Wang Y, Hao WJ, Huang WY. Antibacterial constituents of Hainan Morinda citrifolia (noni) $\begin{array}{llll}\text { leaves. } & \mathrm{J} & \text { Food } & \text { Sci. }\end{array}$ http://doi.org/10.1111/1750-3841.13302

81. Kang JH, Song KB. Antibacterial activity of the noni fruit extract against Listeria monocytogenes and its applicability as a natural sanitizer for the washing of fresh-cut produce. Food Microbiol. https://doi.org/10.1016/j.fm.2019.103260

2019;84:103260.

82. Nugraheni ER, Adriani GR, Munawaroh H. Antibacterial activity of ethyl acetate the extract of noni fruit (Morinda citrifolia 1.) against bacterial spoilage in fish. International
Conference on Food Science and Engineering 2016;193:012019. http://doi.org/10.1088/1757-899X/193/1/012019

83. Luo B, Kastrat E, Morcol T, Cheng H, Kennelly E, Long C. Gaultheria longibracteolata, An alternative source of wintergreen oil. Food Chemistry. 2020;342:128244. https://doi.org/10.1016/j.foodchem.2020.128244

84. Magiera A, Sienkiewicz M, Olszewska MA, Kicel A, Michiel P. Chemical profile and antibacterial activity of essential oils from leaves and fruits of Gaultheria procumbens L. cultivated in poland. Acta Poloniae Pharmaceutical - Drug Research. 2019;76(1):93-102. http://doi.org/10.32383/appdr/94245

85. Salevic A, Prieto C, Cabedo L, Nedovic V, Lagaron JM. Physicochemical, antioxidant and antimicrobial properties of electrospun poly( $\varepsilon$-caprolactone) films containing a solid dispersion of sage (Salvia officinalis L.) extract. Nanomaterials. 2019;9:270. http://doi.org/10.3390/nano9020270

86. Yazgan H. Investigation of antimicrobial properties of sage essential oil and its nanoemulsion as antimicrobial agent. LWT - Food Science and Technology. 2020;130:109669. https://doi.org/10.1016/j.lwt.2020.109669

87. Singh BR. Evaluation of antibacterial activity of Salvia officinalis L. sage oil on veterinary clinical isolates of bacteria. Noteare-medicine. Noto-are 15785463: 2013

88. Cureno HJ, Reyes CR, Garcia IV, Valdez LG, Jesus AG, Ruiz JA, Montoya MJ. Alkaloids of pharmacological importance in Catharanthus roseus. https://doi.org/10.5772/intechopen.82006

89. Lobay D. Rauwolfia in the treatment of hypertension Integrative Medicine. Integr Med (Encinitas). 2015;14(3):40-46. https://www.ncbi.nlm.nih.gov/pmc/articles/PMC4566472/

90. Dar RA, Shahnawaz M, Qazi PH. General overview of medicinal plants: A Review. Int J Phytopharm. 2017;349-51. http://www.phytopharmajournal.com/Vol6_Issue6_08.pdf

91. Amoateng P, Quansah E, Karikari TK, Asase A, Safo DO, Kukuia KK, Amponsah IK, Nyarko AK. Medicinal plants used in the treatment of mental and neurological disorders in Ghana. Evidence Based Complementary Altern Med. 2018.1-14. https://doi.org/10.1155/2018/8590381

92. Anand U, Herrera NJ, Altemimi A, Lakhssassi N. A comprehensive review on medicinal plants as antimicrobial therapeutics: potential avenues of biocompatible drug discovery. Metabolites. 2019;9:258. http://dx.doi.org/10.3390/ metabo9110258

\section{Additional information}

Peer review information: Plant Science Today thanks Sectional Editor and the other anonymous reviewers for their contribution to the peer review of this work.

Reprints and permissions information is available at https://horizonepublishing.com/journals/index.php/PST/open_access_policy

Publisher's Note: Horizon e-Publishing Group remains neutral with regard to jurisdictional claims in published maps and institutional affiliations.

To cite this article: Mayekar V M, Ali A, Alim H, Patel N. A review: Antimicrobial activity of the medicinal spice plants to cure human disease. Plant Science Today. 2021;8(3):629-646. https://doi.org/10.14719/pst.2021.8.3.1152

Plant Science Today, published by Horizon e-Publishing Group, is covered by Scopus, Web of Science, BIOSIS Previews, Clarivate Analytics, etc. See https://horizonepublishing.com/journals/index.php/PST/indexing_abstracting 